Historic, Archive Document

Do not assume content reflects current scientific knowledge, policies, or practices. 


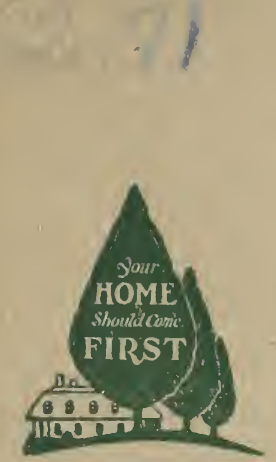

LISFARX

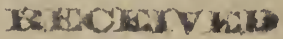

t DEC I'j $1928 \star$

0.8. Deguct of A criontriva

\section{Russellville Nurseries}

East 96th and Burnside Streets

Portland, Oregon

Phone Tabor 0204

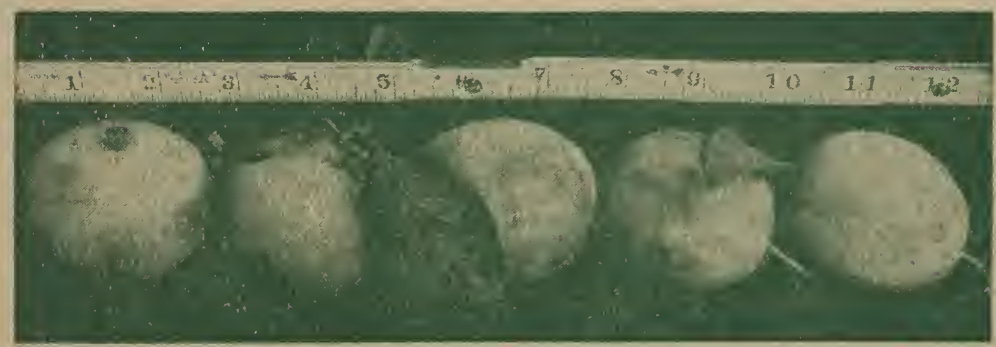

PRINLEW PLUM-A valuable new variety, produced by $H$. A. Lewis. A heavy and sure cropper. Plums of large size; skin yellow, overspread with bright red when fully ripe; a handsome looking plum and the rich, golden flesh is firm, but juicy; fine grained and most delicious of all, either raw or cooked. It's as good as a peach. Stands handling and shipping well. Ripe in August. If you only have room for one plum, plant a Frinlew. Select Tree. 
RUSSELLVILLE NURSERIES adjoin the City Limits of Portland east of the Mt. Tabor district. Our Offices and assembly plant are at East 96th and Burnside Streets-our extensive showgrounds and nurseries are for your convenience and inspection at all times.

Our well drained fertile soil produces Nursery Stock of extra good grade-non-irrigated stock produces splendid fibrous rootsystems. Satisfaction results from selections grown under our system.

You will be pleased with the results obtained from stock grown under such conditions.

INSPECTION. Appreciating the importance of the quick and safe arrival of all shipments to the planter, we exercise every precaution to observe plant quarantine regulatory measures and keep our stock free from insect pests and diseases, hence all plants leaving our hands carry a certificate of inspection.

PRICES are made to fit the quality of the stock sent out. Discriminating buyers now realize that the greatest value of nursery stock is underground. Frequent transplanting and handling specimens with adequate burlapped balls, means success and quick results. It costs more, but it is the fixed policy of the RUSSELLVILLE NURSERIES, and "cheap" stock will not be handled or sent out. The best is always the cheapest. Prices quoted on trees and shrubs in the Ornamental Department are for single plants. Five or more of one variety at $10 \%$ less. Prices on larger quantities upon application.

RESPONSIBILITY. We endeavor to send our patrons the grade and quality of stock ordered. We do not guarantee our products or assume any responsibility after they leave our nursery, as conditions always exist over which we have no control. It is understood, in case of error on our part, that we shall not be responsible for a greater amount than the price paid.

TERMS. Two per cent off for cash before shipment on orders amounting to ten dollars or more. To parties having satisfactory credit arrangement or account with us, one per cent ten days, thirty days net.

No claims for rejection or deficiencies will be entertained unless made within ten days after arrival of goods.

USE THE ORDER BLANK. For the convenience of patrons we enclose a printed form of order blank, which we ask intending purchasers to use; additional copies will be sent on request. Please follow instructions carefully in order to facilitate the safe and prompt arrival of your order. 


\section{ROSES}

fragrance.

“The Rose, the Queen of Flowers." The very name suggests beauty and

There is no group of flowers so universally popular as Roses. For ornamental effects in rows or beds, or as climbing vines they are unsurpassed; and of course as cut flowers there is nothing comparable. Roses are much more effective if segregated in a group by themselves. As a rule they do not combine well with other shrubbery (this does not apply to climbers) and it is only occasionally that they are advisable or effective as single specimens. Tree or Standard roses make good specimens if well trained and carefully tended. belongs :

The abbreviations used refer to the class or group to which the rose

TEA. (T.) This group is of slender growth, not vigorous; however, there are occasional exceptions.

HYBRID TEA. (H. T.) This is the result of hybridizing the hybrid perpetual with the Teas. This group is vigorous and very free flowering, retaining much of the odor of the Tea.

HYBRID PERPETUAL. (H.P.) Hardiest of all types. Growth strong, generally upright; foliage mostly dull; flowers highly perfumed.

PERNETIANA. (Per.) A more recent introduction by Pernet Ducher, of Lyons, France. It is a cross between the Austrian Briar rose and Hybrid Perpetual; the result has produced the most brilliant color combination.

POLYANTHA. (Pol.) This group bears flowers in large clusters.

For best results with Roses we suggest that they be planted before April 1st. (Fall planting is to be preferred.) Dig the beds deep and enrich with well rotted stable fertilizer. Plant your Roses about 18 to 24 inches apart, setting the graft 3 inches below the ground level.

Water them well twice weekly during summer months adding occasional fertilizer solution (a mixture of fertilizer and water). Cultivate the plants occasionally and mulch the soil with a layer of dry straw or leaves.

In February the rose plants should be cut back quite heavily, pruning out all old wood as much as possible to force new growth and better flowers. We shall be pleased to answer any further question pertaining to your particular needs.

\section{PORTLAND ROSEBUSHES}

AMERICA (H. T.)-Light pink blooms, exquisite form, heavy substance. $\$ 1.25$.

BABY CECIL BRUNNER-Rose and cream. 90c.

BABY CRIMSON RAMBLER-Crimson. 90c.

BABY JEANNE D'ARC-Pure white. 90c.

BABY ORLEANS-Geranium red with whitish center. 90c.

BABY PERLE D'OR--Light orange to creamy yellow. 90c.

BABY TAUSENDSCHEON (Thousand Beauties)-Rosy pink. 90c.

BRITISH QUEEN (H.T.)-Pure white, large, full flowers, opening freely. 90c.

CAPTAIN CHRISTY (H. T.)-Flesh, tinted white; fine, large flower, deep green foliage. $90 \mathrm{c}$.

See inside back coier for INDEX 
CAPTAIN HAYWARD (H.P.)-Large, golwing red flushed crimson, deliciously perfumed. $90 \mathrm{c}$.

CONRAD F. MEYER (H. P.)-Hardy, beautiful pure, silvery-pink. Fragrant. $90 \mathrm{c}$.

DOROTHY PAGE ROBERTS (H.T.)-Coppery pink, suffused with apricot yellow. 90c.

DUCHESS OF WELLINGTON (H. T.)-Intense saffron yellow stained with rich crimson. Fragrant. \$1.00.

EARL HAIG (H.T.) (New)-Full, well-modelled blooms, dark crimson. Fragrant. $\$ 1.50$.

ETOILE DE FRANCE (H.T.)-Strong, vigorous grower, dark foliage, beautiful flowers, rich, velvety crimson, vivid cerise-red center. \$1.25.

FRAU KARL DRUSCHKI (H. P.)-The White American Beauty, immense flowers, splendid buds. 90c.

GENERAL JACQUEMINOT (H. P.) - Shining crimson, rich, velvety, large. Rich fragrance. 80c.

GENERAL MacARTHUR (H.T.)-Crimson scarlet, delicious perfume, magnificent foliage. $90 \mathrm{c}$.

GEORGE DICKSON (H. T.)-Large, full, perfect flowers, blackish crimson, velvety. $90 \mathrm{c}$.

GOLDEN EMBLEM[-Peer of all yellow roses. Glossy green foliage. \$1.25.

GOLDEN OPHELIA-Rich golden-yellow, with glossy, dark green foliage. $\$ 1.25$.

GORGEOUS (H. T.)-Flowers deep orange-yellow, finely formed. \$1.00.

GRANGE COLOMBE (H.T.)-Large creamy white, salmon and fawn centers. $\$ 1.00$.

HADLEY-Fine American pedigreed rose, flowers rich crimson scarlet. 90c. HOOSIER BEAUTY (H. T.)-American origin. Flowers dark crimson, buds beautifully formed. 90c.

HUGH DICKSON (H. P.)-Brilliant crimson-scarlet, strong, a favorite variety. $90 \mathrm{c}$.

IRISH ELEGANCE-Bronze orange in bud, flowers lighter. Perpetual blooming. $90 \mathrm{c}$.

IRISH FIREFLAME (H. T.)-Long pointed buds, flowers satiny old gold. $\$ 1.25$.

J. B. CLARKE (H. T.) - Irish variety, color crimson, perfectly formed. 90c.

KAISERIN AUG. VICTORIA (H. T.)-Large pointed buds, double flowers ; creamy-white. 90c.

KILLARNEY BRILLIANT (H.T.)-Deep shell pink, buds exceptionally long and beautifully formed. 90c.

KITCHENER OF KARTOUM (H.T.)-Dazzling scarlet; single flowers in great masses. $\$ 1.00$.

LADY INCHIGUIN (H. T.)-Of marvelous beauty, fine cut-flower, orangecerise. $\$ 2.50$.

LADY ALICE STANLEY (H.T.)-Beautiful, long pointed buds, large, flesh-pink flowers. $\$ 1.00$.

LADY ASHTOWN (H. T.) - Silvery pink. Rare and most beautiful variety. 90c.

LADY HILLINGDON (T.)-Deep apricot yellow, long, pointed buds. Foliage luxuriant. 90c. 
LA FRANCE (H. T.) - Silvery rose and pink. Sweetest of all roses. General favorite. $90 \mathrm{c}$.

LOS ANGELES (H.T.)-Flame pink, beautifully formed. Fragrant and vigorous. $\$ 1.25$.

LOUISE CATHERINE BRESLAU (H. T.) - Carol red, shaded chrome yellow. 90c.

LYON (Pernetiana)-Beautiful shrimp pink. Large coral red buds, beautifully formed. $\$ 1.00$.

MĀMAN COCHET (T.) -Deep rosy pink; buds extremely large, beautifully formed. $90 \mathrm{c}$.

MAMAN COCHET WHITE (T.)-White, often flushed pink. 90c.

MARGARET DICKSON HAMILL-Delicate straw color, fragrant, very distinct. $\$ 1.25$.

MARSHALL P. WILDER (H. P.) - Cherry colored flowers; free bloomer, good grower. 90c.

MISS ALICE ROTHSCHILD (T.) - Light canary-yellow; vigorous and free flowering. $\$ 1.00$.

MME. ABEL CHATENAY (H. T.)-Beautiful rosy carmine, with darker shadings. In great demand. 90c.

MME. BUTTERFLY (H. T.) - Rich harmony of bright pink, apricot and gold. $\$ 1.25$.

MME. CAROLINE TESTOUT (H.T.) - Bright, satiny pink; very fragrant. $90 \mathrm{c}$.

MME. EDOUARD HERRIOTT (Per.) - Color terra cotta bronze and geranium red. $\$ 1.00$.

MME. RAVARY (H. T.) - Clear orange yellow; long pointed buds; flowers of fine form. $\$ 1.00$.

MME. SEGUND WEBER (H. T.) - Light rosy flesh shaded with salmon. Large long pointed buds. $\$ 1.00$.

MRS. AARON WARD (T.) - Deep golden orange color shading to lemon at edge of petals. One of most beautiful roses in existence. \$1.25.

MRS. A. R. WADDELL (H. T.)-Buds, rosy scarlet, flower rich apricot. Foliage is ornamental in itself. 90c.

MRS. CHARLES RUSSELL (H. T.)-Stems three feet long, surmounted by rosy-pink blooms. 90c.

MRS. H. R. DARLINGTON (H. T.)-Pale creamy, enormous flowers, fragrant. (New.) \$1.50.

MRS. J. C. AINSWORTH (H. T.)-Buds peach-blossom pink, flowers crimson-pink at center. Delightfully scented. \$1.25.

OLD GOLD (H. T.) - Flowers a vivid reddish orange color with coppery red shadings. $\$ 1.00$.

OPHELIA (H. T.)-Orange salmon buds, flowers dainty pink. Blooms early and continuously. $90 \mathrm{c}$.

PAUL NEYRON (H.P.)-Deep, shining rose; blooms freely; largest variety in existence. 90c.

PRINCE CHARMING (H. T.)-Deep reddish copper, on old-gold base; a grand rose. $\$ 1.25$.

PRINCE OF BULGARIA (H. T.)-Vigorous. Bright green foliage, flower large and full, rosy flesh color. $\$ 1.00$. 
RADIANCE (H. T.)-Giant growing. Color rich bright cerise, entirely distinct from any other known variety. \$1.25.

RAYON D'OR (Pern.) - Long pointed buds of deep orange-cadmium opening to rich sun-flower yellow. Foliage glossy green. \$1.00.

ROSELANDIA (H. T.) - Typical Ophelia buds, blooms rich golden yellow, fragrant. $\$ 1.50$.

SOUV. DE CLAUDIUS PERNET (H.T.)Large elongated and beautiful formed buds. Color clear brilliant yellow. $\$ 1.25$.

SUNBURST (H. T.) -One of the finest yellow roses. Rich cadmium-yellow, shaded with orange and copper. \$1.25.

TIPPERARY (H. T.) - Beautifully formed buds of bright canary yellow. $\$ 1.25$.

ULRICH BRUNNER (H.P.)-Rich glowing crimson, flamed with scarlet, extra large flowers. 90c.

WHITE LA FRANCE (H. T.) - Silvery white with delicate pink shadings; fragrant. 90c.

WILLOMERE (H. T.) - Buds coral red, opening into large flower of rich shrimp-pink. $\$ 1.25$.

WINNIE DAVIS-Fine apricot pink shading to flesh tint at base of petals. Hardy. 90c.

WILLIAM F. DREER (H.) - Soft shell pink, beautiful in all stages of development. $\$ 1.25$.

\section{CLIMBING ROSES}

AMERICAN BEAUTY-Hardy, color rich red to crimson. Very popular. 90c.

AMERICAN PILLAR-Large, single flowers, rosy pink. 90c.

BLACK BOY-Dark velvety red. $\$ 2.00$.

DOROTHY PERKINS-Beautiful deep pink flowers-too well known for further description. 90c.

DR. VAN FLEET-Color delicate shade of flesh-pink deepening to rosy flesh in center. $\$ 1.00$.

EXCELSA-Red Dorothy Perkins. 90c.

FLOWER OF FAIRFIELD-A counterpart of Crimson Rambler except that it shows everblooming tendencies. 90c.

GENERAL MacARTHUR-Very desirable red climber. $\$ 1.00$.

H.ADLEY-Flowers rich crimson scarlet. \$1.00.

HOOSIER BEAUTY-Deep crimson with darker shadings, strong and vigorous. Like bush variety. $\$ 1.00$.

KAISERIN-Pure white, shading at base of petals to primrose. Strong growing. $\$ 1.00$.

LADY HILLINGDON-Long buds, well-shaped flowers, soft apricot. Fragrant and lasting. $\$ 1.00$.

LA FRANCE-Silvery pink-well known. 90c.

MARECHAL NEIL-Immense deep golden yellow; very fragrant. \$1.25.

MME. ALF. CARRIERE-Oldest white climber. 90c.

MME. C. TESTOUT-Another strong grower with foliage and flowers same as bush, from which it is a sport. 90c. 
MME. ED. HERRIOTT-Brilliant coral red buds and flaming orange-red and salmon flowers. $\$ 1.25$.

PAUL'S SCARLET-Most brilliant rose known, clear, vivid shining scarlet, large semi-double flowers. 90c.

REINE MARIE HENRIETTE-Rich and glowing crimson retaining color in heat of summer. $90 \mathrm{c}$.

SILVER MOON-Very large silvery-white, single. $\$ 1.00$.

SUNBURST-Same as the well-known bush. Strong, vigorous and quite hardy. $\$ 1.00$.

WM. A. RICHARDSON-Copper-yellow, flushed carmine. One of very popular yellow climbing varieties. 90c.

\section{NEW AND RARE VARIETIES DF ROSES}

ANGELE PERNET-Distinct novel type, vivid orange-yellow, to deep apricot. Gold Medal at the Bagatelle Paris trials. $\$ 1.50$.

ARIEL_Flowers large and globular, orange-flame yellow, free blooming. $\$ 1.50$.

BETTY UPRITCHARD (H. T.)-Coppery-red, buds, outer surface brilliant orange-carmine. $\$ 1.50$.

CUBA-Bright vermilion-scarlet, overlying an orange ground. Vigorous grower with dark green foliage. Almost single. \$2.00.

DAINTY-Long, pointed buds, flowers rosy-apricot. Fragrant. \$1.50.

DAME EDITH HELEN-Awarded Gold Medals at New York and Philadelphia Flower shows. Strong and vigorous. Color brilliant, yet soft Rose du Barri pink, very fragrant. $\$ 2.00$.

DIADEM (H.T.)-Large, fragrant double flower of copper-orange, salmon and flame. $\$ 1.50$.

DORIS DICKSON-Exquisite and unique formed, medium-sized flowers. Orange-cream at base, heavily veined and pencilled with deep brilliant cherry. Vigorous, free-flowering and fragrant. \$2.00.

ELDORADO (H.T.)-Golden buds, flushed red, opening to clear yellow, slightly fragrant, blooms late. $\$ 1.50$.

FEU JOSEPH LOOYMANS-Long and pointed buds, large full flowers, yellow with vivid apricot, particularly brilliant at the center. Entirely distinct and novel. $\$ 1.50$.

JOHN RUSSELL (H. T.)-Deep velvety crimson overlaid with black sheen, perfect shape. $\$ 1.50$.

LADY MARGARET STEWART-Awarded Gold Medal by England. A rose of unique and distinct color, deep sunflower yellow in the bud, heavily veined and splashed with orange-scarlet and on reverse side of petals carmine red. $\$ 2.00$.

LORD CHARLEMONT-A most gorgeous and brilliant dark red rose. Clear crimson-scarlet to almost black. Perfectly shaped long pointed buds, large, full double, sweetly scented flowers. $\$ 1.50$.

MARGARET McGREDY-Now offered for the first time. Large, beautifully shaped full double flowers. Color, oriental red. $\$ 2.50$.

MARY PICKFORD (H. T.) —Long, pointed bud, dark orange yellow, flowers light orange-yellow. $\$ 1.50$. 
MONSIEUR JULIEN POTIN-(The Golden Pernet.)-Brilliant rich golden that grows richer and deeper as the flower matures. Long shapely buds, with glossy, bronzy-green foliage, very attractive. $\$ 2.50$.

MRS. HENRY BOWLES-Splendidly shaped, long ovid buds, developing into perfect high-centered full double flowers. Luminous deep salmonpink. A vigorous grower and perpetual bloomer. $\$ 1.50$.

NORMAN LAMBERT-Deep chrome-yellow with a marginal color effect of brilliant orange-scarlet to a suffused bronze, shading to yellow at the base. Very unusual. $\$ 2.50$.

REIMS (H. T.)—Long, pointed bud. Flesh-pink. New. \$2.50.

REV. F. PAGE ROBERTS-A rose of remarkable beauty both in form and color. The long pointed buds of coppery-red, stained red on outside, opening to double fragrant flowers of golden yellow. Beautiful foliage. $\$ 1.50$.

MABEL MORSE-Good-sized flower of the richest clear, bright goldenyellow. Strong, vigorous grower, free flowering, with glossy foliage. $\$ 1.50$.

SOUV. DE GEORGES PERNET-Strong, vigorous grower, intense Oriental red, shading to carmine at the margin of the petals, the whole being suffused with a golden sheen. $\$ 1.50$.

VILLE DE PARIS (H. T.) - Round buds of clear yellow and large globular flowers untouched by any other color. \$2.00.

\section{STANDARD OR TREE ROSES}

These differ from the ordinary bush, in that they are grafted on upright stems several feet in height. These have been very scarce this year. We can supply the following varieties. See general list for descriptions.

Price $\$ 3.50$ each unless otherwise noted.

Duchess of Wellington
Frau Karl Druschki
General MacArthur
Golden Emblem
Gruss an Teplitz, $\$ 3.00$
Hoosier Beauty
Hugh Dickson, $\$ 3.00$
Kaiserin Aug. Victoria

Lady Hillingdon

Los Angeles

Mme. C. Testout, $\$ 3.00$

Mme. Ed. Herriot

Ophelia

Souv. de C. Pernet

Ulrich Brunner, $\$ 3.00$

Vm. F. Dreer

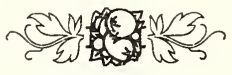

Please feel at liberty to consult us on any particular Rose Problem you may have in hand. 


\section{CONIFERS}

Conifer or Cone Bearing trees always come with Ball and Burlap. They have been transplanted several times in the nursery-row to insure fine fibrous roots and when ready for market are generally three to five or perhaps seven years old.

In these as well as in all other lines, an assortment of "Specimen Stock" can be quoted upon request.

Describe your place and we shall suggest the proper tree for it.

The Conifers herein quoted have been properly trained and cared for and will give absolute satisfaction.

\section{CONIFER - HARDY EVERGREENS}

\section{ARBORVITAE, Thuja-}

AMERICAN, T. occidentalis-Soft, deep green; pyramidal.

30 to 36 in., $\$ 3.00$ each;

24 to 30 in., $\$ 2.50$ each

COMPACT, T. occ. compacta-Slow growing, compact, oval. Fine specimen.

$$
\begin{aligned}
& 18 \text { to } 24 \text { in., } \$ 3.00 \text { each } \\
& 15 \text { to } 18 \text { in., } \$ 2.50 \text { each; } \\
& 12 \text { to } 15 \text { in., } \$ 2.25 \text { each; }
\end{aligned}
$$

GLOBE, T. occ globosa-Globe-shaped, green, hardy. Foreground and tub plantings.

15 to 18 in., $\$ 2.75$ each;

12 to 15 in., $\$ 2.25$ each;

HOVEY'S, T. occ. hoveyi-Similar to Globosa.

15 to 18 in., $\$ 2.75$ each;

12 to 15 in., $\$ 2.25$ each;

PEABODY, T. occ. lutea-Pyramidal, yellow green.

18 to 24 in., $\$ 3.50$ each;

15 to 18 in., $\$ 2.00$ each;

PYRAMIDAL, T. occ. pyramidalis-Pyramidal, columnar. Fernlike, verdant green.

30 to 36 in., $\$ 3.50$ each;

24 to 30 in., $\$ 3.00$ each;

WARE'S, T. occ. wareana-Nearly globular, sage green, compact.

18 to 24 in., $\$ 4.00$ each;

15 to 18 in., $\$ 3.50$ each;

12 to 15 in., $\$ 3.00$ each;

WOODWARD, T. occ. woodwardi-Globe to $3 \mathrm{ft}$. high and wide. Tub, low foundation.

15 to 18 in., $\$ 3.50$ each;

12 to 15 in., $\$ 2.50$ each;

ERECT NATIVE CEDAR, T. occ. plicata fastigiata-Columnar form.

Erect pyramid.

$$
4 \text { to } 5 \mathrm{ft} \text {., } \$ 3.00 \text { each; }
$$

3 to 4 ft., $\$ 2.25$ each;

NATIVE CEDAR, T. occ. plicata-Graceful, drooping. Dark green. Price same as above 
ORIENTAL, T. orientalis-Pyramidal, bushy, compact, bright green.

3 to $4 \mathrm{ft} ., \$ 2.75$ each;

30 to 36 in., $\$ 2.25$ each;

BERKMAN'S GOLD., T. or aurea nana-Dwarf Golden, compact, symmetrical.

15 to 18 in., $\$ 3.50$ each;

12 to 15 in., $\$ 3.00$ each;

GOLDEN ORIENTAL, T. or. aurea-Compact, globosa, golden to bright green.

30 to 36 in., $\$ 3.50$ each;

24 to 30 in., $\$ 3.00$ each;

ORIENTAL PYRAMIDAL, T. or. pyramidalis-Pyramidal, bright green, tall.

30 to 36 in., $\$ 3.00$ each;

24 to 30 in., $\$ 2.50$ each;

FALSE or HIBA, Thujopsis dolabrata-Loose-growing pyramidal, very distinct. Coarse green foliage.

18 to 24 in., $\$ 3.00$ each;

15 to 18 in., $\$ 2.50$ each;

CEDAR, Cedrus-

BLUE ATLAS CEDAR, C. Atlantica glanca-Similar to Mt. Atlas

Cedar, deep blue foliage.

30 to 36 in., $\$ 4.50$ each;

24 to 30 in., $\$ 4.00$ each;

CEDAR OF LEBANON, C. Libani-Resembles Atlantica very closely, slightly different outline.

30 to 36 in., $\$ 3.00$ each;

24 to 30 in., $\$ 2.50$ each;

HIMALAYA CEDAR, C. Deodora-Graceful drooping branches, distinct light green foliage.

4 to $5 \mathrm{ft}$., $\$ 6.00$ each;

3 to 4 ft., $\$ 4.00$ each;

30 to 36 in., $\$ 2.50$ each;

24 to 30 in., $\$ 2.00$ each;

MT. ATLAS CEDAR, C. Atlantica-Vigorous, hardy, open tree, bunched bright green foliage.

30 to 36 in., $\$ 3.00$ each;

24 to 30 in., $\$ 2.50$ each;

CRYPTOMERIA, Cryptomeria-

COMMON, C. japonica-Deep green foliage changing to brown.

30 to 36 in., $\$ 3.00$ each;

24 to 30 in., $\$ 2.50$ each;

18 to 24 in., $\$ 2.00$ each;

PLUME, C. Jap elegans-Fine, dense, bronze green foliage.

30 to 36 in., $\$ 4.00$ each;

24 to 30 in., $\$ 2.50$ each;

18 to 14 in., $\$ 2.00$ each; 
CYPRESS, Chamaecyparis-

LAWSON, C. lawsoniana (Port Orford Cedar)-Blue-green foliage, compact branches. Fairly rapid growth.

3 to $4 \mathrm{ft}$., $\$ 2.75$ each;

24 to 30 in., $\$ 2.50$ each;

18 to 24 in., $\$ 2.00$ each;

GREEN COLUMN, C. lazusoniana erecta viridis-Upright, symmetrical habit; foliage rich green.

30 to 36 in., $\$ 4.50$ each;

24 to 30 in., $\$ 2.50$ each;

18 to 24 in., $\$ 2.75$ each;

BLUE LAWSON, C. law. alumi (Scarab Cy.) - Similar to above, steelflue foliage.

3 to $4 \mathrm{ft}$., $\$ 4.50$ each;

30 to 36 in., $\$ 3.50$ each;

24 to 30 in., $\$ 3.00$ each;

TRIOMPHE DE BOSKOOP, C. law. glanca-Light blue foliage and pendulous branches.

30 to 36 in., $\$ 4.00$ each;

24 to 30 in., $\$ 3.50$ each;

DWARF LAWSON, C. law. nana-Low growing Cypress.

15 to 18 in. spread, $\$ 3.50$ each;

12 to 15 in. spread, $\$ 2.75$ each;

WISSEL, C. law. wisseli-Rich blue foliage; columnar habit.

30 to 36 in., $\$ 7.50$ each;

24 to 30 in., $\$ 5.00$ each;

HINOKI, C. obtusa-Spreading, graceful habit, fan-shaped branchlets. Flat, green foliage.

30 to 36 in., $\$ 7.50$ each;

24 to 30 in., $\$ 5.00$ each;

GOLD. HINOKI, C. obtusa aurea-Similar to above with golden foliage. 30 to 36 in., $\$ 7.50$ each;

24 to 30 in., $\$ 5.00$ each;

DWARF JAP., C. obtusa nana-Very dwarf Hinoki Cypress.

18 to 24 in., $\$ 7.50$ each;

12 to 18 in., $\$ 4.50$ each;

SAWARA, C. pisifera-Green, flat foliage, horizontal drooping branches. 24 to 30 in., $\$ 3.25$ each; 18 to 24 in., $\$ 2.75$ each;

GOLDEN SAWARA, C. pisifera aurea-Same as above with golden tips. 24 to 30 in., $\$ 3.50$ each;

18 to 24 in., $\$ 3.00$ each;

PLUME RETINISPORA, C. pisifera plumosa-Delicate, graceful, feathery foliage, dense upright habit. 24 to 30 in., $\$ 3.00$ each; 18 to 24 in., $\$ 2.50$ each;

GOLDEN PLUME RET., C. pisifera plum. aurea-Similar to above, attractive with golden foliage.

24 to 30 in., $\$ 3.50$ each;

18 to 24 in., $\$ 3.00$ each;

See inside back cover for INDEX 
MOSS RE'T., C. pisifera squarrosa (veitchi)-Densely compact, light bluish grey foliage, feathery branchlets.

$$
24 \text { to } 30 \text { in., } \$ 3.50 \text { each; }
$$

SQUARROSA RET., C. $p$. squarrosa-Same as above, dwarf habit, darker foliage.

18 to 24 in., $\$ 3.00$ each;

12 to 18 in., $\$ 2.50$ each;

FIR, Abies-

BALSAM, A. balsamea-Fragrant slender growing tree. Dark green foliage.

24 to 30 in., $\$ 2.50$ each;

18 to 24 in., $\$ 2.00$ each;

NORDMANN'S, A. nordmanniana-Angular branching habit. Deep green.

24 to 30 in., $\$ 3.00$ each;

18 to 24 in., $\$ 2.50$ each;

WHITE, A. concolor-Queen of all the Firs. Foliage deep blue, long flat needles, attractive. Hardy.

30 to 36 in., $\$ 3.50$ each;

24 to 30 in., $\$ 3.00$ each;

HEMLOCK, Tsuga-

CANADA, T. canadensis-Yew-like foliage. Can be sheared.

30 to 36 in., $\$ 3.50$ each;

24 to 30 in., $\$ 3.00$ each;

MOUNTAIN, T. mertensiana-Tall, graceful, slender pendulous branchlets, verdant green foliage.

30 to 36 in., $\$ 3.00$ each;

24 to 30 in., $\$ 2.50$ each;

WESTERN, T. heterophylla-Short, slender, pendulous branchlets. 30 to 36 in., $\$ 3.00$ each;

24 to 30 in., $\$ 2.50$ each;

INCENSE CEDAR, Libocedrus-

CALIFORNIA, L. decurrens-Truly a sweet scented cedar-tall pyramid. 30 to 36 in., $\$ 3.50$ each;

JUNIPER, Juniperus-

CHINESE, J. chinensis-Pyramidal compact, dense green foliage.

24 to 30 in., $\$ 3.50$ each;

18 to 24 in., $\$ 2.75$ each;

WHITELEAF CHINESE, J. chinensis albo var.-Same as above with silver tips.

24 to 30 in., $\$ 3.50$ each;

18 to 24 in., $\$ 3.00$ each;

CREEPING CHINESE, J. chinensis procumbens-Dense low-spreading, foliage grayish-green.

24 to 30 in. spread, $\$ 3.50$ each;

18 to 24 in. spread, $\$ 3.00$ each; 
COMMUNIS, J.. communnis-Pyramidal, dark blue foliage. Changing darker in winter.

24 to 30 in., $\$ 3.00$ each;

IRISH, J. comm. hibernica-Slender columnar compact, silvery-grey, sharp needles.

3 to $4 \mathrm{ft} ., \$ 5.00$ each;

30 to 36 in., $\$ 4.00$ each;

24 to 30 in., $\$ 3.00$ each;

18 to 24 in., $\$ 2.50$ each;

PFITZER'S, J. pfitzeriana-Broad pyramid. Trailing juniper.

30 to 36 in. spread, $\$ 3.50$ each;

24 to 30 in. spread, $\$ 3.00$ each;

SAVIN, J. sabina-Semi-spreading, bluish gray-green foliage.

30 to 36 in. spread, $\$ 3.50$ each;

24 to 30 in. spread, $\$ 3.00$ each;

RED CEDAR, J. Virginiana-Pyramidal, densely branched, thick foliage.

30 to 36 in., $\$ 3.00$ each;

24 to 30 in., $\$ 2.50$ each;

18 to 24 in., $\$ 2.25$ each;

PINE, Pinus-

AUSTRIAN, P. nigra austriaca-Long, dark, coarse needles, upright growth.

30 to 36 in., $\$ 3.50$ each;

24 to 30 in., $\$ 3.00$ each;

MUGHO, P. mughus-Densely branched, semi-spreading habit. Dark green.

15 to 18 in. spread, $\$ 3.00$ each;

WESTERN YELLOW, P. ponderosa-Hardy, deep green, slightly drooping.

30 to 36 in., $\$ 3.00$ each;

24 to 30 in., $\$ 2.50$ each;

SPRUCE, Picea-

COLORADO BLUE, P. pungens glauca-Stiff symmetrical. Pungent foliage varying from green to blue.

30 to 36 in., $\$ 5.00$ each;

24 to 30 in., $\$ 4.00$ each;

18 to 24 in., $\$ 3.50$ each;

KOSTER BLUE, P. pungens kosteri-Improved strain of Colorado. Deep steel-blue foliage. Grafted.

18 to 24 in., $\$ 10.00$ each;

15 to 18 in., \$ 7.50 each;

NORWAY, P. excelsa-Rapid growing, dark green needles.

3 to $4 \mathrm{ft}$., $\$ 3.00$ each;

30 to 36 in., $\$ 2.50$ each;

24 to 30 in., $\$ 2.00$ each;

See inside back cover for INDEX 
YEW, Taxus-

ENGLISH, T. baccata-Slow growing, numerous spreading branches.

Dark green foliage.

$$
18 \text { to } 24 \text { in., } \$ 5.00 \text { each; }
$$

IRISH, T. baccata fastigiata-Compact, upright. Foliage glossy darkgreen.

24 to 30 in., $\$ 7.00$ each;

18 to 24 in., $\$ 5.50$ each;

15 to 18 in., $\$ 3.50$ each;

VARIEGATED IRISH, T. baccata fastigiata aurea-Same as above with golden variegated foliage.

18 to 24 in., $\$ 8.00$ each;

15 to 18 in., $\$ 6.00$ each;

CANADIAN, T. canadensis-Dwarf evergreen. Drooping branchlets, dark green foliage.

18 to 24 in., $\$ 3.50$ each;

15 to 18 in., $\$ 3.00$ each;

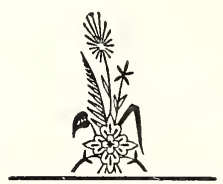

Being so wonderfully endowed by beautiful surroundings-beautiful trees and splendid soil conditions, we of the Pacific Northwest can scarcely realize the wonderful possibilities at hand.

Why not capitalize these many advantages and co-operate with nature to advance our local conditions!!!

'Tis said that environment affects the Man-why cannot man control his environment?

Trees and Shrubs properly planted will provide your home with those intimate associations that will linger in the minds of yourself and your friends for truly it may be said "It's not a Home until it's Planted."

Every day you are Judged by the Appearance of Your Home Grounds.

It is our suggestion that you endeavor to carry out a definite plan of planting-may we consult with you, our suggestions are yours for the asking. 


\section{BROAD LEAF EVERGREENS}

Evergreen Shrubs or Broadleaf Evergreens always come with Ball and Burlap on the roots to insure their growing. Planting instructions and arrangement suggestions are furnished with each order, upon request.

Much satisfaction can be derived from the judicious selection of Evergreens, which provide color and background for your garden throughout the year.

Consistent care and culture in the Nursery are necessary to produce good Broad Leaf Evergreen shrubs. Those herein listed are first class only.

\section{BROAD LEAF EVERGREENS}

ABELIA, Abelia-

A. Grandiflora-Attractive. Glossy bronzy-green leaves, clusters of pinkish-white flowers.

$$
24 \text { to } 30 \text { in., } \$ 1.50 \text { each; }
$$

18 to 24 in., $\$ 1.25$ each;

ANDROMEDA, Andromeda-

A. Leucothoe racemosa-Small, with erect branches. Leaves oblong, pointed. Bell-shaped white flowers, April to June.

18 to 24 in., $\$ 4.50$ each;

15 to 18 in., $\$ 3.00$ each;

ARALIA, Aralia-

A. sieboldi (Fatsia Japonica)-Semi-tropical, large compound leaves. Blooms terminal creamy white flowers.

24 to 30 in., $\$ 1.50$ each;

18 to 24 in., $\$ 1.00$ each;

AUCUBA, Aucuba-

JAPANESE LAUREL, A. japonica-Dark green glossy leaves, red berries in winter.

$$
\begin{aligned}
& 24 \text { to } 30 \text { in., } \$ 2.50 \text { each; } \\
& 18 \text { to } 24 \text { in., } \$ 1.75 \text { each; }
\end{aligned}
$$

JAP. GOLD DUST LAUREL, A. japonica variegata-Similar to above, foliage very finely splotched yellow.

24 to 30 in., $\$ 2.50$ each;

18 to 24 in., $\$ 1.75$ each;

AZALEA, Azalea-

EVERGREEN JAP., A. hinodegiri-Flowers bright crimson in June.

Shiny leaves turning brown in Fall.

15 to 18 in. spread, $\$ 3.00$ each;

12 to 15 in. spread, $\$ 2.50$ each;

KIUSIANA, A. Obtusa-Similar to above with spreading habit.

15 to 18 in. spread, $\$ 3.00$ each;

12 to 15 in. spread, $\$ 2.50$ each;

See inside back cover for INDEX 
BARBERRY, Berberis-

MAGELLAN, B. buxifolia-Dwarf plant, small dark green leaves, small orange flower, dark purple berries.

12 to 15 in., $\$ 1.50$ each;

8 to 12 in., $\$ 1.00$ each;

DARWIN, B. daraini-Semi-spreading, with small holly-like leaves. Flowers, bright yellow, dark-purple berries.

18 to 24 in., $\$ 1.50$ each;

15 to 18 in., $\$ 1.00$ each;

ROSEMARY, B. stenophylla-Spiny branches, small dark green leaves.

Yellow flowers, small dark fruit.

24 to 30 in., $\$ 1.50$ each;

18 to 24 in., $\$ 1.00$ each;

WILSON, B. wilsonae-Dense bushy habit of growth. Yellow flowers. 18 to 24 in., $\$ 1.50$ each;

15 to 18 in., $\$ 1.00$ each;

BOX, (Boxwood), Buxus-

JAPANESE, B. japonica-Medium slow-growing bushy shrub. Round, light green leaves.

$$
\begin{aligned}
& 15 \text { to } 18 \text { in., } \$ 2.50 \text { each; } \\
& 12 \text { to } 15 \text { in., } \$ 2.00 \text { each; }
\end{aligned}
$$

TRUE TREE, B. sempervirens (arborescens)-Dark glossy green foliage. Clipped specimen $\$ 2.00$ per foot.

15 to 18 in., $\$ 2.50$ each;

12 to 15 in., $\$ 2.00$ each;

TRUE DWARF, B. semperitens suffruiticosa-For low borders and window boxes.

10 to 12 in., $\$ 5.00$ per 10

8 to 10 in., $\$ 4.00$ per 10

BROOM, Cytisus and Genista-

BRIDAL-VEIL, G. monosperma-Flowers white. Earlier than Scotch Broom.

24 to 30 in., $\$ 1.50$ each;

18 to 24 in., $\$ 1.00$ each;

KEW, G. kewensis-Low growing, globe shaped; bright yellow blooms. 24 to 30 in., $\$ 1.50$ each;

18 to 24 in., $\$ 1.00$ each;

PARADISE, C. scoparius andreamus-Pea-shaped flowers, side petals deep mahogany red; free bloomer.

24 to 30 in., $\$ 2.00$ each;

18 to 24 in., $\$ 1.50$ each;

SCOTCH, C. scoparius-Upright growth, limber twigs, yellow flowers in early Spring.

18 to 24 in., $\$ 1.00$ each;

15 to 18 in., $\$ .75$ each;

SPANISH, G. hispanica-Perpetual bloomer, sweet scented yellow flowers.

24 to 30 in., $\$ 1.50$ each;

18 to 24 in., $\$ 1.00$ each; 
CAMELliA, Camellia-

C. Japonica-Dark green glossy leaves. Wax-like flowers in early Spring. Flowers red, white, or pink and variegated.

18 to 24 in. (medium), $\$ 3.00$ each;

15 to 18 in. (medium), $\$ 2.50$ each;

12 to 15 in. (medium), $\$ 2.00$ each;

\section{COTONEASTER, Cotoneaster-}

DIEL'S, C. Dielsiana-Moderately tall growing, oval-shaped dark green leaves, crimson berries.

$$
\begin{aligned}
& 24 \text { to } 30 \text { in., } \$ 1.50 \text { each; } \\
& 18 \text { to } 24 \text { in., } \$ 1.00 \text { each; }
\end{aligned}
$$

FRANCHET, C. franchetti-Medium size, open growing. Pendulous gray-green foliage. Red berries.

24 to 30 in., $\$ 1.50$ each;

18 to 24 in., $\$ 1.00$ each;

ROCK, C. horizontalis-Low spreading, bright red berries all winter.

18 to 24 in. spread, $\$ 1.75$ each;

15 to 18 in. spread, $\$ 1.50$ each;

12 to 15 in. spread, $\$ 1.00$ each;

HUMIFUSA, C. humifusa-Low growing-rockery shrub. New.

15 to 18 in. spread, $\$ 1.50$ each;

12 to 15 in. spread, $\$ 1.00$ each;

ROCKSPRAY, C. microphylla-Vigorous spreading; bright green leaves. Evergreen. Light red berries.

18 to 24 in. spread, $\$ 1.00$ each;

15 to 18 in. spread, \$.75 each;

SILVERLEAF, C. pannosa-Upright, graceful habit, leaves green, silver color beneath. Berries light red.

24 to 30 in., $\$ 1.50$ each;

18 to 24 in., $\$ 1.00$ each;

SIMONS, C. simonsi-Tall growing, glossy foliage. Pinkish white flowers, bright red fruit.

3 to $4 \mathrm{ft} ., \$ 1.50$ each;

30 to 36 in., $\$ 1.00$ each;

24 to 30 in., $\$ .75$ each;

DAPHNE, Daphne-

ROSE DAPHNE, D. cneorum-Low spreading, short slender leaf, dark green. Pink fragrant flowers throughout summer.

12 to 15 in. spread, $\$ 2.50$ each;

10 to 12 in. spread, $\$ 2.00$ each;

WINTER DAPHNE, D. odora-Light green foliage, white bordered, fragrant flowers. White or purple.

24 to 30 in., $\$ 4.00$ each;

18 to 24 in., $\$ 3.00$ each;

15 to 18 in., $\$ 2.50$ each;

See inside back cover for INDEX 
ESCALLONIA, Escallonia-

WHITE, E. pulverulenta alba-Large spreading shrub, shiny leaves. Flowers white.

24 to 30 in., $\$ 2.00$ each;

18 to 24 in., $\$ 1.50$ each;

PINK, E. pul. macrantha-Same as above. Pink flowers, low growing. 18 to 24 in., \$1.50 each;

RED, E. pul. rubra-Same as above with red flowers.

18 to 24 in., $\$ 1.50$ each;

RED, NEW, E. langleyensis-Hardy, red flowering Escallonia.

18 to 24 in., $\$ 1.50$ each;

EUONYMUS, Eyonymus-

SPINDLE TREE, E. japonica-Upright growth, smooth dark green foliage.

24 to 30 in., $\$ 1.50$ each;

18 to 24 in., $\$ 1.00$ each;

GOLD. SPINDLE TREE, E. jap. aurea-Same as above. Leaves splotched with gold. Slow growth.

24 to 30 in., $\$ 2.00$ each;

18 to 24 in., $\$ 1.50$ each;

SILVER SPINDLE TREE, E. jap. alba marginata-Leaves green with narrow white edging.

18 to 24 in., $\$ 2.00$ each;

15 to 18 in., $\$ 1.50$ each;

FIRETHORNE, Pyracantha-

LALAND, P. coccinea lalandi-Similar to above, upright growth. Fruit orange yellow.

24 to 30 in., $\$ 2.00$ each;

18 to 24 in., $\$ 1.25$ each;

NARROWLEAF, P. angustifolia-Tall grower, leaves long, narrow, large berries, yellow in winter.

24 to 30 in., $\$ 1.75$ each;

18 to 24 in., $\$ 1.25$ each;

NEPAL, P. crenulata-Long narrow foliage, more glossy and dense.

24 to 30 in., $\$ 2.00$ each;

18 to 24 in., $\$ 1.25$ each;

SCARLET, P. coccinea-Somewhat dwarf with bright green foliage. Orange scarlet berries.

24 to 30 in., $\$ 2.00$ each;

18 to 24 in., $\$ 1.25$ each;

YUNAN, P. unanensis-Spreading habit, oval leaves. Red fruits.

24 to 30 in., $\$ 2.00$ each;

18 to 24 in., $\$ 1.25$ each; 
HEATH, Erica-

SPRING, E. carnearosea-Low growing, flowers pink. Hardy.

15 to 18 in. spread, $\$ 1.50$ each;

12 to 15 in. spread, $\$ 1.25$ each;

8 to 12 in. spread, $\$ 1.00$ each;

BISCAY, E. mediterranea (Mediterranean Heather)-Strong grower, dark green foliage. Pink flowers.

$$
\begin{array}{r}
15 \text { to } 18 \text { in., } \$ 1.50 \text { each; } \\
12 \text { to } 15 \text { in., } \$ 1.00 \text { each; } \\
8 \text { to } 12 \text { in., } \$ .75 \text { each; }
\end{array}
$$

CORNISH, E. vagans-Beautiful dark foliage, flowers purplish red in late summer.
15 to 18 in., $\$ 1.50$ each;
12 to 15 in., $\$ 1.00$ each;

HEATHER, Calluna vulgaris-

SCOTCH, C. vulgaris-Low dense shrub, pink flowers.

12 to 15 in., $\$ 1.25$ each;

10 to 12 in., $\$ 1.00$ each;

8 to 10 in., $\$ .75$ each;

WHITE SCOTCH, C. vulgaris alba-White flowers.

15 to 18 in., $\$ 1.25$ each;

12 to 15 in., $\$ 1.00$ each;

8 to 12 in., $\$ .75$ each;

SWEDISH BELL, C. sueica-Hardy, upright, attractive pink flowers.

15 to 18 in., $\$ 1.25$ each;

12 to 15 in., $\$ 1.00$ each;

8 to 12 in., $\$ .75$ each;

HOLLY, Ilex-

ENGLISH, I. aquifolia-Tall growing, crinkey spiny foliage. Berries red.

3 to 4 ft., $\$ 3.50$ each;

2 to $3 \mathrm{ft} ., \$ 2.75$ each;

18 to 24 in., $\$ 2.00$ each;

DUTCH, I. aquifolia pyramidalis-Upright foliage less spiny than English. Prolific fruiter.

3 to $4 \mathrm{ft}$., $\$ 3.50$ each;

2 to $3 \mathrm{ft}$., $\$ 2.75$ each;

JAPANESE, I. crenata-Compact; small bright foliage, black berries.

2 to 3 ft., $\$ 3.00$ each;

18 to 24 in., $\$ 2.50$ each;

VARIEGATED, I. jerado variegata-Both gold and silver variegation. Berries red.

2 to $3 \mathrm{ft}$., $\$ 3.50$ each;

18 to 24 in., $\$ 3.00$ each;

HONEYSUCKLE, Lonicera-

EVERGREEN, L. nitida-Bushy shrub, small leaves. Can be sheared. 18 to 24 in., $\$ 1.00$ each;

PRIVET, L. pileata-Dwarf spreading, foliage dark green, glossy.

18 to 24 in. spread, $\$ 1.50$ each;

15 to 18 in. spread, $\$ 1.00$ each;

See inside back cover for INDEX 
LAUREL, Laurus-

ENGLISH, Laurocerasus officinalis-Bright, large, dark green foliage.

2 to $3 \mathrm{ft} ., \$ 1.00$ each;

18 to 24 in., $\$ .75$ each;

PORTUGAL, L. lusitanica-Dark green leaf. Growth compact. High class shrub. Hardy.

18 to 24 in., $\$ 2.50$ each;

15 to 18 in., $\$ 1.50$ each;

SWEET BAY (Grecian Laurel), L. nobilis-Bushy bright leaves. Fine tub plant.

15 to 18 in., $\$ 3.00$ each;

LAURISTINUS, Viburnum timus-

Bushy; foliage dark green. Winter bloomer, pinkish white flowers.

2 to 3 ft., $\$ 2.25$ each;

18 to 24 in., $\$ 1.50$ each;

MOUNTAIN LAUREL, Kalmia latifolia (Calico Bush)-

Dark green, cluster flowers rose to white.

18 to 24 in., $\$ 2.50$ each;

MEXICAN ORANGE, Choisya ternata-

Compact and bushy. Light green foliage, white flowers at tips of branches.

18 to 24 in., $\$ 2.50$ each;

15 to 18 in., $\$ 2.00$ each;

PERNETTYA, Pernettya-

DAVIES HYBRID-Mixed colored berries-low growth compact.

15 to 18 in., $\$ 2.50$ each;

12 to 15 in., $\$ 2.00$ each;

MUCRONATA-Red and purple fruit, broad-leaf.

12 to 15 in., $\$ 2.00$ each;

SPECIOSA-Fruit, scarlet red.

12 to 15 in., $\$ 2.00$ each;

PHOTINIA, glabra-

Dark glossy foliage, red fruits.

2 to $3 \mathrm{ft} ., \$ 2.25$ each;

18 to 24 in., $\$ 1.50$ each;

PRIVET, Ligustrum-

JAPANESE, L. japonicum-Upright; dark green foliage. Flowers white, dark berries.

24 to 30 in., $\$ 1.00$ each;

GLOSSY, L. lucidum-Large spreading, larger leaves, less hardy than Japanese.

24 to 30 in., $\$ 1.00$ each;

AMUR, L. amurense-Upright branches, leaves oval, glossy above. 24 to 30 in., $\$ 1.00$ each;

GOLDEN, L. ovalifolium var.-Leaves variegated yellow, quite showy. 18 to 24 in., $\$ 1.00$ each;

REGEL, L. regelianum-Low dense shrub with showy leaves.

18 to 24 in., $\$ 1.00$ each; 
SPEEDWELL, Veronica-

BOXLEAF, V. buxifolia-Small glossy leaves; compact round. 12 to 15 in., $\$ .75$ each;

CYPRESS, V. cupressoides-Cypress-like foliage, distinct, quick growing. Globular form.

12 to 15 in., $\$ .75$ each;

THYMELEAF, V. thymifolia-Similar to Buxifolia, slightly faster growth.

12 to 15 in., $\$ .75$ each;

GLAUCUS, V. glaucophylla-Semi-spreading compact, silvery grey leaf. 12 to 15 in., $\$ .75$ each;

BUSH, V. traversii-Upright compact; green.

15 to 18 in., $\$ .75$ each;

AMPLEXLEAF, V. amplexicaulis-Spreading shrub, quite large foliage. Somewhat different.

12 to 15 in., $\$ .75$ each;

\section{VIBURNUM, Viburnum-}

SWEET, V. odoratissimum-Attractive; upright growth, branches stout, laurel-like leaf. Fragrant white flowers.

15 to 18 in., $\$ 1.50$ each;

LEATHER-LEAF, V. rhytidophyllum-Leaves 6 to 8 inches, bronzy green, roughened. Berries red to shining black.

15 to 18 in., $\$ 1.50$ each;

The three fundamental rules of Landscape Gardening are:

1. Plant in masses.

2. Avoid straight lines.

3. Leave open spaces.

Consult us on your Landscape Plans. 


\section{DECIDUOUS FLOWERING SHRUBS}

Flowering Shrubs afford a rotation of hardy flowers each year without continued transplanting.

The usual cultivating, fertilizing and watering will add much to their beauty and vigor.

We solicit inquiry as to your individual requirements and will gladly make suggestion as to how you may best select and arrange your Shrubs.

ALMOND, Prunus-

PINK FLOWERING, P. glandulosa-Dwarf shrub, double pink roses, gracefully bending branches.

2 to 3 feet, $\$ 1.50$ each;

WHITE FLOWERING, P. glandulosa-Same, though white flowers.

2 to 3 feet, $\$ 1.50$ each;

ALTHEA, Hibiscus syriacus (Rose of Sharon)-

ALTHEAS, free-growing shrub to $5 \mathrm{ft}$., flowering in August and September. Hardy.

Double Red, Boule de Feu

Pink, Amplissima

Double Flesh, Paeoniflora

Rosy White, Lady Stanley

2 to 3 feet, $\$ 1.00$ each;

AZALEA, Azalea-

ALTA CLARE, A. altaclarensis-Semi-dwarf; large clusters bright yellow flowers.

12 to 15 in., $\$ 3.00$ each;

CHINESE, A. mollis-Flowers before leaves. Colors, pink, white, yellow or salmon orange.

12 to 15 in., $\$ 3.00$ each;

WESTERN, A. occidentalis-Large shrub, white or pink flowers in May. Does well in shade. Very fragrant.

18 to 24 in., $\$ 2.50$ each;

BARBERRY, Berberis-

JAPANESE, B. thunbergi-Dwarf, bushy. Foliage green, coppery red in Fall. Red berries.

18 to 24 in., $\$ .75$ each;

NEW RED-LEAF, B. atropurpureum-Dwarf.

15 to 18 in., $\$ 1.50$ each;

WILSON, B. wilsonae-Low growing, very thorny, small red fruits.

12 to 15 in. spread, $\$ 1.00$ each;

BUTTERFLY BUSH, Buddleia magnifica-

Fast growing shrub, semi-evergreen. Flowers purple, fragrant spikes June till November.

3 to 4 feet, $\$ .75$ each; 
BUCKTHORNE, Rhamnus cathartica-

COMMON-Attains $12 \mathrm{ft}$--thorny. Leaves oval.

2 to 3 feet, $\$ .75$ each;

BURNINGBUSH, Euonymus Eup.-

Upright shrub, attractive foliage; handsome in fall, scarlet berries.

2 to 3 feet, $\$ 1.00$ each;

CEANOTHUS, Ceanothus (Wild Lilac)-

Bushy effect. Purple flowers.

18 to 24 in., $\$ 1.00$ each;

CRANBERRY BUSH, Viburnum opulus-

Tall growing Snowball-red fruits in fall.

2 to 3 feet, $\$ 1.00$ each;

CINQUEFOIL (Shrubby), Potentilla fruiticosa-

Much branched, with peculiar sheddy bark. Numerous bright yellow flowers.

$$
18 \text { to } 24 \text { in., } \$ 1.00 \text { each; }
$$

DEUTZIA, Deutzia-

DOUBLE ROSE, D. scabra plena-Pink blossoms, slender racemes four to six in. long.

2 to 3 feet, $\$ 1.00$ each;

FUZZY, D. scabra crenata-Double white flowers tinged rose, late June. 2 to 3 feet, $\$ 1.00$ each;

DEUTZIA, (continued)-

LEMOINE-Flowers pure white; shrub dwarf.

18 to 24 in., $\$ 1.00$ each;

PRIDE OF ROCHESTER-Large white flowers, tinged rose.

2 to 3 feet, $\$ 1.00$ each;

SLENDER, D. gracilis-Dwarf habit; flowers white; blooms May. 15 to 18 in., $\$ 1.00$ each;

WATERER, D. scabra wateri-Double white flowers, tinged pink. 15 to 18 in., $\$ 1.00$ each;

DOGWOOD, Cornus-

FLOWERING, C. florida-Large white blossoms, red berries and red foliage in fall.

4 to 5 feet, $\$ 1.50$ each;

RED-OSIER, C. stolonifera-Dwarf form. Bark red, flowers white. White berries.

18 to 24 in., $\$ 1.00$ each;

RED-TWIGGED, C. sanguinea-Bright red branches. Small white blossoms early summer.

2 to 3 feet, $\$ .75$ each;

See inside back cover for INDEX 
ELDER, Sambucus-

CUTLEAF EUROPEAN, S. nigra laciniata-Shrub, dark green foliage deeply cut.

3 to 4 feet, $\$ 1.00$ each;

RED-BERRIED, S. pubens-Deep green foliage, red fruit.

3 to 4 feet, $\$ 1.00$ each;

SIEBOLD, S. sieboldi-Foliage strongly marked with creamy white.

2 to 3 feet, $\$ 1.00$ each;

FILBERT, Corylus-

Purple, C. avellana atropurpurea-Spreading growth; good among other shrubs.

2 to 3 feet (Bushy), $\$ 1.50$ each

FORSYTHIA, Forsythia-

BORDER, F. intermedia-Long drooping branches with golden blossoms.

3 to 4 feet, $\$ 1.00$ each;

FORTUNE, F. suspensa fortunei-Shrub medium size; bright yellow flowers early in spring; foliage dark green.

3 to 4 feet, $\$ 1.00$ each;

GREENSTEM, F. viridissima-Flowers deep yellow before the leaves.

3 to 4 feet, $\$ 1.00$ each;

WEEPING, F. suspensa-Tall long drooping branches with golden blossoms.

2 to 3 feet, $\$ 1.00$ each;

HONEYSUCKLE, Lonicera-

MORROW, L. morrowi (Bush Honeysuckle)-Upright grower, pure white flowers. Red berries.

18 to 24 in., $\$ 1.00$ each;

PINK TARTARIAN, L. $t$. rosea-Pink flowers.

18 to 24 in., $\$ 1.00$ each;

RED TARTARIAN, L. $t$. rubra-Flowers beautiful, bright red early in spring.

18 to 24 in., $\$ 1.00$ each;

WHITE TARTARIAN, L. $t$. alba-Creamy white, fragrant flowers. May, June.

18 to 24 in., $\$ 1.00$ each;

WINTER, L. fragrantissima-Winter bloomer, white flowers, sweet scented.

18 to 24 in., $\$ 1.00$ each; 
HYDRANGEA, Hydrangea-

HOUSE, H. opuloides-From Japan, flowers, pink or blue, dark green leaves.

$$
\begin{aligned}
& 15 \text { to } 18 \text { in., } \$ 1.50 \text { each; } \\
& 12 \text { to } 15 \text { in., } \$ 1.00 \text { each; }
\end{aligned}
$$

PEEGEE, H. panticulata grandiflora-Tall shrub, leaves bright green; flowers in huge panicles, in August.

18 to 24 in., $\$ 1.50$ each;

15 to 18 in., $\$ 1.00$ each;

PEEGEE (standards)-Same as above in tree form.

3 to 4 feet, $\$ 3.00$ each;

2 to 3 feet, $\$ 2.00$ each;

SMOOTH, H. arborescens-Handsome foliage, showy white clusters of flowers. Does well in the sun.

18 to 24 in., $\$ 1.00$ each;

SNOWHILL, H. arborescens sterilis_Flowers resembling Snowball, continuous blooming.

18 to 24 in., $\$ 1.00$ each;

INDIGOBUSH, Amorpha fruticosa-

Large spikes, pea-shaped flowers.

18 to 24 in., $\$ 1.00$ each;

KERRIA, Kerria-

GLOBEFLOWER, K. japonica (Japanese Rose)-Slender, upright stems and branches. Orange double flowers, blooms all summer. Hardy. 2 to 3 feet, $\$ 1.00$ each;

SILVER-Dwarf shrub, small green foliage edged white, rose-like deep yellow flowers in April.

15 to 18 in., $\$ 1.00$ each;

LILAC, Syringa-

COMMON PURPLE, S. vulgaris-Flowers purple, fragrant.

2 to 3 feet, $\$ 1.00$ each;

COMMON WHITE, S. vulgaris alba-Flowers white, fragrant.

2 to 3 feet, $\$ 1.00$ each;

DOUBLE BLUE-Deep purple, sweet scented flowers. Grafted.

24 to 30 in., $\$ 1.50$ each;

DOUBLE WHITE-Rich creamy white, double blooms.

24 to 30 in., $\$ 1.50$ each;

See inside back cover for INDEX 
MOCK-ORANGE, Philadelphus (Syringa)-

BIG SCENTLESS, P. grandiflorius-Robust with large white flowers.

18 to 24 in., $\$ .75$ each;

GORDON, P. Gordonianus-Large floriferous, not scented.

18 to 24 in., $\$ .75$ each;

LEWIS, P. lezvisi (Western)-Medium grower, flowers large, abundant. 18 to 24 in., $\$ 1.00$ each;

MANTEAU I'HERMINE-Dwarf, small leaves, dense growth. Small white flowers.

18 to 24 in., $\$ .75$ each;

SWEET, P. coronarius-Blooms early; highly scented.

18 to 24 in., $\$ .75$ each;

VIRGINAL, P. lemoinei-Large double, fragrant flowers.

2 to 3 feet, $\$ 1.00$ each;

ZEYHER, P. zeyheri-Spreading, arching branches. Flowers slightly fragrant.

18 to 24 in., $\$ .75$ each;

NINEBARK, Physocarpus-

GOLDLEAF, P. opulifolius luteus-Shrub, golden foliage, erect; whitish flowers late spring.

15 to 18 in., $\$ .75$ each;

PEARLBUSH, Exochorda-

COMMON, E. grandiflora-Blooms early, white and showy. 18 to 24 in., $\$ 1.00$ each;

PEA-SHRUB, Caragana-

SIBERIAN PEA-TREE, C. arborescens-Showy dwarf tree or shrub, with pea-shaped flowers.

4 to 5 feet, $\$ 1.50$ each;

PHOTINIA, Photinia-

VILLOSA-Upright shrub, slender spreading branches. Flowers white. Red fruits.

2 to 3 feet, $\$ 1.50$ each;

POMEGRANITE, Punica-

COMMON, P. granatum-Bushy growth. Slender twiggy branches, leaves glossy green. Flowers red.

2 to 3 feet, $\$ 1.50$ each; 
PRIVET, Ligustrum-

IBOTA, L. ibota-Very hardy shrub to 10 feet, with spreading branches. 2 to 3 feet, $\$ .75$ each;

REGEL, L. i. regelianum-Low dense shrub with horizontal spreading branches; fine hedge plant.

2 to 3 feet, $\$ .75$ each;

CALIFORNIA, L. ovalifolium-Semi-evergreen-showy green leaves. 2 to 3 feet, $\$ .75$ each;

CHINESE, L. sinensis-Spreading, small leaf shrub.

2 to 3 feet, $\$ .75$ each;

COMMON, L. vulgare-Shrub to 15 feet; fine dark green foliage and panicles of blue-black fruit.

2 to 3 feet, $\$ .75$ each;

GOLDEN, L. ovalifolium aureum-Golden leaf California Privet.

2 to $3 \mathrm{ft}$., $\$ 1.50$ each;

18 to 24 in., $\$ 1.00$ each;

QUINCE, Cydonia-

FLOWERING, C. japonica-Flowers bright scarlet crimson, early spring ; foliage glossy green.

18 to 24 in., $\$ 1.00$ each;

ROCKSPIREA, Holodiscus-

OCEANSPRAY SPIREA, H. discolor ariaefolius-Slender arching branches, panicles of creamy white flowers.

2 to 3 feet, $\$ 1.00$ each;

RUSSIAN-OLIVE, Eleagnus-

E. Angustifolia (Oleaster)-Small tree, foliage silvery, oval yellow fruit. 18 to 24 in., $\$ 1.00$ each;

SNOW BALL, Viburnum-

COMMON, V. opulus sterile-Old fashioned snowfall; May.

2 to 3 feet, $\$ 1.00$ each;

JAPANESE, V. plicatum-Shrub to $6 \mathrm{ft}$., covered with flat white blooms in June.

18 to 24 in., $\$ 1.50$ each;

DOUBLEFILE, V. tomentosum-Slightly faster growing than above. 18 to 24 in., $\$ 1.00$ eách;

SNOWBERRY, Symphoricarpos-

COMMON, S. racemosus-Valuable in shady places; berries pure white; flowers rose colored.

2 to 3 feet, $\$ .75$ each;

CORALBERRY, S. vulgaris-Spreading habit; slender branches; currant-like fruit.

2 to 3 ft., $\$ 1.00$ each;

18 to 24 in., $\$ .75$ each;

See inside back cover for INDEX 
SPIREA, Spiraea-

ANTHONY WATERER, S. anthony waterer-Showy, crimson flowers; useful low shrub.

15 to 18 in., $\$ .75$ each;

BUMALDA, S. bumalda-Compact growing, dense foliage; flowers flat clusters. 18 to 24 in., $\$ .75$ each;

DOUBLE BRIDALWREATH, S. prunifolia plena-Flowers dense racemes along slender branches; dark green foliage.

18 to 24 in., \$.75 each;

JAPANESE PINK, S. japonica ruberrima-Dull green leaves; dark flowers; low shrub.

15 to 18 in., $\$ .75$ each;

JAPANESE WHITE, S. $j$. ovalifolia-Upright shrub, profuse bloomer; flowers pure white in flat topped clusters.

18 to 24 in., $\$ .75$ each;

ORIENTAL, S. media-Leaves light green; pure white flowers.

18 to 24 in., \$.75 each;

REEVES, S. reevesiana-Medium size, long leaves; flowers pure white. 15 to 18 in., $\$ .75$ each;

THUNBERG S. thumbergi-Slender branches, green, dense foliage; early white flowers in long racemes.

15 to 18 in., $\$ .75$ each;

VANHOUTTE, S. vanhouttei-Handsome and useful; flowers in flat clusters; foliage deep green.

18 to 24 in., $\$ .75$ each;

WILLOWLEAF, S. salicifolia-Foliage, dull green; flowers in narrow panicles.

18 to 24 in., $\$ .75$ each;

TAMARIX, Tamarix-

AFRICAN, T. africana-Leaves similar to the Juniper; flowers pink, small, delicate, on long spikes, in May.

18 to 24 in., \$ .75 each;

WEIGELA, Weigela-

DWARF VARIEGATED, W. hybrida nana var.-Light pink flowers. Leaves variegated.

18 to 24 in., $\$ 1.00$ each;

EVA RATHKE, W. Eva rathke-Red flowers, throughout summer.

18 to 24 in., $\$ 1.00$ each;

PINK, W. rosea-Light pink blossoms.

2 to 3 feet, $\$ 1.00$ each;

SNOW, W. hybrida candida-Pure white flowers.

18 to 24 in., $\$ 1.00$ each;

VANHOUTTE, W. hybrida vanhouttei-Flowers deep rosy red.

2 to 3 feet, $\$ 1.00$ each; 


\section{HEDGE PLANTS}

BARBERRY, Berberis-

JAPANESE, B. thunbergi-Flowers small; bright red fruits in winter; foliage red in autumn.

18 to 24 in., $\$ 40.00$ per 100 ;

12 to 18 in., $\$ 30.00$ per 100 ;

BOX, Buxus-

TRUEDWARF, B. sempervirens sufruticosa-Round leaf, dwarf form; for edging beds and walks.

6 to 8 in., $\$ 25.00$ per 100 ;

4 to 6 in., $\$ 15.00$ per 100 ;

GOLDEN, B. s. aurea

SILVER, B. s. argentea

Common box wood with variegated leaves.

6 to 8 in., $\$ 30.00$ per 100 ;

TRUETREE, B. s. arborescens-Tall growing larger leaves.

8 to 12 in., $\$ 30.00$ per 100 ;

PRIVET, Ligustrum-

CALIFORNIA, L. ovalifolium

EUROPEAN, L. vulgare

IBOTA, L. ibota

18 to 24 in., $\$ 25.00$ per C.

12 to 18 in., $\$ 15.00$ per C.

OREGON GRAPE, Mahonia aquifolium-

18 to 24 in., $\$ 60.00$ per 100 ;

12 to 18 in., $\$ 50.00$ per 100 ;

\section{AMHARHAR}

Many other Shrubs and Trees are often used for hedge purposes.

Please consult us as to desirability, quality and price. 


\section{VINES AND CLIMBERS}

AMERICAN BITTERSWEET, Celastrus scandens-

Handsome, glossy foliage; clusters orange-crimson fruits all winter. $\$ 1.50$ each;

CLEMATIS, Clematis-

C. Henryi-Flowers creamy-white, large.

$\$ 1.50$ each;

C. Jackmani-One of the best. Strong grower, violet-purple flowers. Large.

$\$ 1.50$ each;

C. Madam Edouard Andre-Flowers crimson; free bloomer. $\$ 1.50$ each;

SWEET AUTUMN, C. Paniculata-Beautiful. Luxuriant grower, profuse bloomer, fine foliage.

$\$ 1.00$ each;

DUTCHMAN'S PIPE, Aristolochia-

A. Sipho (Birthwort)-Large, heart shaped leaves, pipe-shaped yellowish brown flowers.

$\$ 1.00$ each;

EUONYMUS, Euonymus-

BIGLEAF WINTERCREEPER (E. radicans vegetus)-(Evergreen). Low, hardy, evergeen; clusters of berries; leaves thick, dark.

$\$ 1.00$ each;

SILVEREDGE WINTERCREEPER (E. $r$. argenteo-marginatus) (Evergreen) leaves rather small; silvery white around edge.

$\$ 1.00$ each;

HONEYSUCKLE, Lonicera-

HALL'S JAPAN (L. japonica halleana)—(Evergreen). Strong vigorous white flowers to yellow. Fragrant-good bloomer.

$\$ 1.00$ each;

MONTHLY FRAGRANT H., (Woodbine), L. periclymenum, var Belgica-Blooms all summer; flowers red and yellow; fragrant.

$\$ 1.00$ each;

SCARLET TRUMPET, L. sempervirens-Strong grower; flowers bright scarlet.

$\$ 1.00$ each;

IVY, Hedera-

ENGLISH, H. helix-Evergreen clinging and penetrating tendrilsnot suited near buildings.

$\$ 1.00$ each;

AMERICAN, Ampelopsis quinquefolia (Virginia Creeper)-Rapid grower. Changes to scarlet in autumn.

$\$ 1.00$ each;

BOSTON, A. tricuspidata (veitchi) (Japan Creeper)-Clinging foliage, dense, green and red.

$\$ .75$ each; 
JASMINE, Jasminum-

WINTER, J. nudiflorum-Smooth angular branches. Flowers golden yellow, before leaves.

$\$ 1.00$ each;

WHITE, J. officinale-White clusters sweet scented flowers. $\$ 1.50$ each;

PERIWINKLE, Vinca-

COMMON, V. minor-For banks and under trees, good ground cover. $\$ .50$ each;

TRUMPET CREEPER, Bignonia radicans-

Vigorous, leaves compound, trumpet-shape flowers. $\$ 1.00$ each;

WISTERIA, Wistaria-

CHINESE PURPLE, W. sinensis-Rapid growth, flowers pale-blue in long clusters.

$\$ 1.50$ each;

CHINESE WHITE, W. sinensis, var. alba-Same as above. Pure white. $\$ 1.50$ each;

JAPANESE, W. multijuga-Long cluster. One of the best-deep purple flowers.

$\$ 2.00$ each; 


\section{DECIDUOUS TREES (Shade Trees)}

In landscaping your home the larger growing trees are the first that should be planted-these may often be put in, years before the building is put up.

We are always ready to suggest proper arrangement and assist in your plan to "Build for Beauty."

\section{SHADE TREES}

ASH, Fraxinus-

BLACK, F. nigra-Native West Coast; flowers yellowish white, fragrant. June.

$$
6 \text { to } 8 \mathrm{ft} \text {., } \$ 1.50 \text { each; }
$$

GREEN, F. lanceolata-Handsome, light green sawtooth leaves.

6 to $8 \mathrm{ft} ., \$ 1.50$ each;

WHITE, F. americana-Rapid growing, symmetrical.

6 to $8 \mathrm{ft}$., $\$ 1.50$ each;

BIRCH, Betula-

EUR. WHITE, B. alba-Beautiful tree, white bark, slender branches.

$$
\begin{aligned}
& 8 \text { to } 10 \mathrm{ft} \text {., } \$ 2.50 \text { each; } \\
& 6 \text { to } 8 \mathrm{ft} \text {, } \$ 1.75 \text { each; } \\
& 4 \text { to } 6 \mathrm{ft} \text {., } \$ 1.00 \text { each; }
\end{aligned}
$$

CUT-LEAF, WEEPING, B. laciniata-One of the best shade trees for lawn and street.

$$
\begin{aligned}
& 8 \text { to } 10 \mathrm{ft} ., \quad \$ 5.00 \text { each; } \\
& 6 \text { to } 8 \mathrm{ft} ., \quad \$ 2.50 \text { each; } \\
& 5 \text { to } 6 \mathrm{ft} ., \quad \$ 1.00 \text { each. }
\end{aligned}
$$

BOXELDER, Acer Negundo-

ASH LEAF MAPLE, A. negundo

6 to $8 \mathrm{ft}$., $\$ 1.50$ each;

5 to $6 \mathrm{ft} ., \$ 1.25$ each;

SILVER VARIEGATED, A. negundo argentia var.-Mottled green and white leaves.
4 to $5 \mathrm{ft} ., \$ 2.00$ each;
3 to $4 \mathrm{ft} ., \$ 1.75$ each;

GOLDEN VARIEGATED, A. neg. auratum-Same as above, golden foliage. Faster grower.

4 to $5 \mathrm{ft.}$, $\$ 2.00$ each;

3 to $4 \mathrm{ft} ., \$ 1.75$ each;

\section{CATALPA-}

UMBRELLA, C. bungei-Umbrella-shaped top, symmetrical. For lawn, park and cemetery planting.

$6 \mathrm{ft} ., 3 \mathrm{yr}$. head, $\$ 5.00$ each;

6 ft., 2 yr. head, $\$ 3.50$ each;

$6 \mathrm{ft} ., 1 \mathrm{yr}$. head, $\$ 2.50$ each;

WESTERN, C. speciosa-Broad, deep green leaves, large white blossoms. 6 to $8 \mathrm{ft}$., $\$ 1.50$ each;

5 to $6 \mathrm{ft}$., $\$ 1.00$ each; 


\section{CHERRY, Prunus-}

JAPANESE FLOWERING, P. avium plena-Large double pink flowers, in large clusters.
5 to $6 \mathrm{ft}$., $\$ 4.00$ each;
4 to $5 \mathrm{ft}$., $\$ 3.00$ each;
3 to $4 \mathrm{ft}$., $\$ 2.00$ each;

JAPANESE WEEPING, P. fruiticosa pendula-Branches slender; flowers rose-colored, before the leaves.
5 to $6 \mathrm{ft}$,
4 to 5 ft., 2 yr. head,
$\$ 7.50$ each;
$\$ 5.00$ each;

CRAB, Malus-

BECHTEL, M. ioensis plena-Medium growth, fragrant double flowers, delicate pink.
4 to $5 \mathrm{ft} ., \$ 2.00$ each;
3 to 4 ft., $\$ 1.50$ each;

JAPANESE, M. floribunda-Pink flowering buds, white flowers; small yellow fruit.

3 to $4 \mathrm{ft} ., \$ 1.50$ each;

RED FLOWERING, M. sanguinium-Pointed cut-leaf drooping branches, red flowers.

3 to $4 \mathrm{ft} ., \$ 1.50$ each;

REDVEIN, M. niedzwetskyana-Red color of flowers, branches, leaves and fruit.

3 to $4 \mathrm{ft} ., \$ 1.50$ each;

SCHEIDECKER, M. scheideckeri-Pyramidal habit; small, bright rosecolored flowers.

5 to $6 \mathrm{ft} ., \$ 1.50$ each;

DOGWOOD, Cormus-

PACIFIC, C. nuttalli-Native Pacific Northwest, immense white flowers in April.

6 to $8 \mathrm{ft}$., $\$ 2.00$ each;

RED-OSIER, C. stolonifera-Medium size, spreading, dark red bark. white flowers.

4 to $5 \mathrm{ft} ., \$ 1.50$ each;

\section{ELM, Ulmus-}

AMERICAN WHITE, U. americana-Magnificent tree with drooping branches.
8 to $10 \mathrm{ft} ., \$ 2.25$ each;

6 to $8 \mathrm{ft}$., $\$ 1.75$ each;

CORK BARK, U. alatus-Young branches, very corky.

8 to $10 \mathrm{ft}$., $\$ 2.25$ each;

6 to $8 \mathrm{ft} ., \$ 1.75$ each;

ENGLISH, U. campestris-Rapid grower, erect, compact. Dark green. 8 to $10 \mathrm{ft} ., \$ 2.25$ each;

6 to $8 \mathrm{ft} ., \$ 1.75$ each;

SIBERIAN, U. pumila-Graceful, medium fast grower; slightly drooping branches.

6 to $8 \mathrm{ft}$., $\$ 2.00$ each;

5 to $6 \mathrm{ft}$., $\$ 1.50$ each;

See inside back cover for INDEX 


\section{GOLDENCHAIN-}

Laburnum vulgare-Clover-shaped leaves; long chains golden yellow; fragrant flowers.

6 to $8 \mathrm{ft} ., \$ 2.00$ each;

\section{HAWTHORNE, Crataegus-}

CARRIERE, C. carrierei-Handsome small tree; white flowers, bright red fruit.

$$
\begin{aligned}
& 6 \text { to } 8 \mathrm{ft} ., \quad \$ 2.50 \\
& 5 \text { to } 6 \mathrm{ft} \text {., } \$ 1.75 \text { each; }
\end{aligned}
$$

PAUL'S DOUBLE SCARLET, C. oxyacantha splendius-Bright scarlet flowers, dull red berries.

6 to $8 \mathrm{ft} ., \$ 3.00$ each;

5 to $6 \mathrm{ft}$., $\$ 2.50$ each;

4 to $5 \mathrm{ft}$., $\$ 2.00$ each;

WHITE, C. monogyna alboplena-Fragrant white, double flowers.

$$
\begin{aligned}
& 6 \text { to } 8 \mathrm{ft} \text {., } \$ 2.50 \text { each; } \\
& 5 \text { to } 6 \mathrm{ft} \text {., } \$ 2.00 \text { each; }
\end{aligned}
$$

\section{HORSECHESTNUT, Aesculus-}

WHITE, A. hippocastanum-Handsome tree, panicles of white flowers followed by horny-husked nuts.

$$
8 \text { to } 10 \mathrm{ft} \text {., } \$ 3.00 \text { each; }
$$$$
6 \text { to } 8 \mathrm{ft} \text {., } \$ 2.50 \text { each; }
$$

RED, A. rubricunda-Flowers red-more dwarf growing.

6 to $8 \mathrm{ft}$., $\$ 4.00$ each;

5 to $6 \mathrm{ft}$., $\$ 3.00$ each;

LINDEN (Basswood), Tilia-

AMERICAN, T. americana-Shapely, handsome. Medium fast growing.

Large leaf.

$$
\begin{aligned}
& 6 \text { to } 8 \mathrm{ft} \text {., } \$ 2.00 \text { each; } \\
& 5 \text { to } 6 \mathrm{ft} \text {., } \$ 1.50 \text { each; }
\end{aligned}
$$

EUROPEAN, T. vulgaris-Sweet scented, peculiar flowers and seed. 6 to $8 \mathrm{ft}$., $\$ 2.00$ each;

5 to $6 \mathrm{ft} ., \$ 1.50$ each;

LOCUST, Robinia-

COMMON BLACK, R. pseudacacia-Rapid growing; flowers in long pendulous racemes, white.

6 to $8 \mathrm{ft}$., $\$ 1.50$ each;

5 to $6 \mathrm{ft} ., \$ 1.00$ each;

HONEY, Gleditsia triacanthos-Rapid growing, powerful spines, delicate foliage.

6 to $8 \mathrm{ft}$., $\$ 2.00$ each;

5 to $6 \mathrm{ft}$., $\$ 1.50$ each;

MOSS LOCUST, R. hispada (Rose Acacia)-Clusters pink flowers late summer. (High headed recommended.)

6 to $8 \mathrm{ft}$., $2 \mathrm{yr}$. head, $\$ 10.00$ each; 


\section{MAIDENHAIR TREE-}

GINKGO BILOBA-Slow glower; foliage like Maidenhair fern. fern.
6 to $8 \mathrm{ft}$., $\$ 2.50$ each;
5 to $6 \mathrm{ft}$., $\$ 2.00$ each;
4 to $5 \mathrm{ft} ., \$ 1.50$ each;

MAPLE, Acer-

NORWAY, A. platanoides-Handsome tree, compact growth.
8 to $10 \mathrm{ft}$., $\$ 2.50$ each;
6 to $8 \mathrm{ft}$., $\$ 2.00$ each;
5 to $6 \mathrm{ft}$., $\$ 1.50$ each;

OREGON, A. macrophyllum-Graceful tree, large foliage, rapid growth. 6 to $8 \mathrm{ft}$., $\$ 2.00$ each;

5 to $6 \mathrm{ft}$., $\$ 1.50$ each;

SCHWEDLER, A. Platanoides schwedleri-Large bronze-red leaves, young growth. Most ornamental tree.
6 to $8 \mathrm{ft}$., $\$ 2.50$ each;
5 to $6 \mathrm{ft}$., $\$ 2.00$ each;

SILVER, A. dasycarpum-Rapid growing; foliage bright green, silver beneath.
8 to $10 \mathrm{ft}$., $\$ 2.50$ each;
6 to $8 \mathrm{ft}$., $\$ 2.00$ each;

SYCAMORE, A. pseudoplatanus_Extra large foliage, very hardy.

8 to $10 \mathrm{ft}$., $\$ 2.00$ each;

6 to $8 \mathrm{ft}$., $\$ 1.50$ each;

5 to $6 \mathrm{ft}$., $\$ 1.00$ each;

SYCAMORE PURPLE LEAF, A. pseudoplatanus purpurascens-Pur ple-leaf Sycamore Maple. 6 to $8 \mathrm{ft}$., $\$ 2.50$ each;

SUGAR, A. saccharum-Upright growth, dense.

8 to $10 \mathrm{ft}$., $\$ 2.50$ each;

6 to $8 \mathrm{ft} ., \$ 2.00$ each;

VINE, A. circinatum-Round headed tree or shrub; light green foliage turning to orange and scarlet in fall.
6 to $8 \mathrm{ft}$., $\$ 2.50$ each;
5 to $6 \mathrm{ft}$., $\$ 2.00$ each;
4 to $5 \mathrm{ft}$., $\$ 1.50$ each;

WIERS CUTLEAF, A. saccharinium wieri-Graceful cut-leaf, drooping branches.

$$
6 \text { to } 8 \mathrm{ft} \text {., } \$ 2.50 \text { each; }
$$

JAPANESE, A. palmatum-Leaves copper green; good as specimen.

5 to $6 \mathrm{ft}$., $\$ 2.00$ each;

4 to $5 \mathrm{ft}$., $\$ 1.50$ each;

SPIDERLEAF, A. palmatum ornatum (Japanese Red Lace Leaf)Small, low growing tree, spreading.

15 to 18 in. spread, $\$ 5.00$ each;

DWARF, A. palmatum atropurpureum-Very handsome, leaves crimson, red.

4 to $5 \mathrm{ft} ., \$ 5.00$ each;

See inside back cover for INDEX 
MULBERRY, Morus-

DOWNING, M. alba-Yields large, refreshing black berries.

5 to $6 \mathrm{ft}$., $\$ 2.00$ each;

RUSSIAN, M. alba tatarica-Hardy, used for windbreaks. Foliage used as silk-worm feed.

5 to $6 \mathrm{ft}$., $\$ 1.50$ each;

4 to $5 \mathrm{ft}$., $\$ 1.00$ each;

MOUNTAIN ASH, Sorbus-

AMERICAN, S. americana-Very ornamental. Red berries most of the winter.

6 to $8 \mathrm{ft} ., \$ 2.00$ each;

5 to $6 \mathrm{ft}$., $\$ 1.50$ each;

EUROPEAN, S. aucuparia-White flowers, red berries. Handsome. 6 to $8 \mathrm{ft}$., $\$ 2.00$ each;

5 to $6 \mathrm{ft}$., $\$ 1.50$ each;

OAK, Quercus-

CHESTNUT, Q. prunus-Growth moderately fast, desires well drained soil.

6 to $8 \mathrm{ft} ., \$ 2.50$ each;

5 to $6 \mathrm{ft}$., $\$ 2.00$ each;

COMMON, Q. rubra-Foliage cut sharp, dark red. Sturdy.

6 to $8 \mathrm{ft}$., $\$ 2.50$ each;

5 to $6 \mathrm{ft}$., $\$ 2.00$ each;

ENGLISH, Q. robur-Dark green leaves; dense.

6 to $8 \mathrm{ft}$., $\$ 2.50$ each;

5 to $6 \mathrm{ft}$., $\$ 2.00$ each;

SCARLET, Q. coccinea-Leaves finely cut, bright green to brilliant scarlet.

6 to $8 \mathrm{ft}$., $\$ 2.50$ each;

5 to $6 \mathrm{ft}$., $\$ 2.00$ each;

PEACH, Amygdalus-

DOUBLE PINK, A. rosea-plena-Brilliant and beautiful. Blossoms appearing before the leaves.

3 to $4 \mathrm{ft}$., $\$ 2.00$ each;

2 to $3 \mathrm{ft} ., \$ 1.50$ each;

DOUBLE WHITE, A. albo-plena-Similar to above, white flowers. Same price as above

PLANE, Platanus-

AMERICAN, P. occidentalis-Broad foliage, handsome bark.

8 to $10 \mathrm{ft}$., $\$ 2.50$ each;

6 to $8 \mathrm{ft}$., $\$ 2.00$ each;

ORIENTAL, P. orientalis-Erect growing, mottled trunk. Bright green sawtooth foliage.

8 to $10 \mathrm{ft}$., $\$ 2.50$ each;

6 to $8 \mathrm{ft}$., $\$ 2.00$ each; 
PLUM, Prunus-

DOUBLE FLOWERING, P. triloba-Flowers double, pink, inch in diameter.

4 to $5 \mathrm{ft} ., \$ 1.75$ each;

3 to $4 \mathrm{ft}$., $\$ 1.50$ each;

PURPLE LEAF, P. pissardi-Upright ; foliage bronzy purple, red, round fruit.

6 to $8 \mathrm{ft}$., $\$ 2.50$ each;

5 to $6 \mathrm{ft}$., $\$ 2.00$ each;

PURPLE LEAF, P. thunder cloud-Dark red leaves turning lighter in fall.

Same prices as above

PURPLE LEAF, P. vesuvious-Leaf light to dark purple later.

Same prices as above

PINK FLG, P. bleriana-Similar to Pissardi in habit. Double pink flowers.

Same prices as above

POPLAR, Populus-

BALM OF GILEAD, P. candicans-Fast growing. Leaves broad.

6 to $8 \mathrm{ft} ., \$ 1.50$ each;

5 to $6 \mathrm{ft}$., $\$ 1.00$ each;

BOLLEANA, P. bolleana-Tall columnar; foliage silvery white.

Same prices as above

CANADIAN, P. deltoides-Hardy. Far north.

Same prices as above

CAROLINA, P. eugenei-Strong growing, columnar.

Same prices as above

LOMBARDY, P. nigra italica-Towering growth.

Same prices as above

SILVER, P. alba nivea-Compact grower. Leaves glossy green above and silvery beneath.

6 to $8 \mathrm{ft} ., \$ 2.00$ each;

5 to $6 \mathrm{ft} ., \$ 1.50$ each;

REDBUD, Cercis-

AMERICAN, C. canadensis-Low growing, conspicuous flowers appear before leaves.

4 to $5 \mathrm{ft} ., \$ 1.50$ each;

3 to $4 \mathrm{ft} ., \$ 1.25$ each;

SUMAC, Rhus-

SMOOTH, R. glabra-Low tree, open crown. Leaves bright green, scarlet in fall. Flowers in clusters, crimson fruits.

5 to $6 \mathrm{ft}$., $\$ 2.00$ each;

4 to $5 \mathrm{ft} ., \$ 1.50$ each;

CUT LEAF, R. glabra laciniata-Large leaves, finely cut, graceful habit. Same price as above

STAGHORN, R. hirta-Leaves beautifully formed, rival delicate fern. Same price as above

See inside back cover for INDEX 


\section{SWEET GUM-}

Liquidambar styraciflua-Slow growth; leaves star shaped, bright color in fall.

5 to $6 \mathrm{ft}$., $\$ 2.50$ each;

4 to $5 \mathrm{ft} ., \$ 2.00$ each;

TULIPTREE, Liriodendron-

L. tulipifera-Leaves light, glossy green; greenish yellow, tulip shaped flowers.

6 to $8 \mathrm{ft}$., $\$ 2.00$ each;

\section{WEEPING (or) PENDULOUS DECIDUOUS TREES}

\section{BIRCH, Betula-}

CUTLEAF WEEPING, B. alba laciniata-White bark, drooping branches, finely cut foliage.

8 to $10 \mathrm{ft} ., \$ 4.00$ each;

6 to $8 \mathrm{ft}$., $\$ 3.00$ each;

5 to $6 \mathrm{ft} ., \$ 2.25$ each;

CHERRY, Prunus-

JAPANESE WEEPING (Shidare-higan,) P. subhirtella pendula-Dainty tree, slender, graceful branches, flowers rose pink before leaves. See Shade Trees for Price.

ELM, Ulmus-

CAMPERDOWN, U. glabra camperdown-Long pendulous branches, good lawn arbor.

5 to $6 \mathrm{ft} ., 2$ yr. head, $\$ 5.00$ each;

MULBERRY, Morus-

TEAS WEEPING, M. alba tatarica pendula-Small tree, drooping; dense, green foliage.

5 to $6 \mathrm{ft} ., 2$ yr. spread, $\$ 5.00$ each;

WILLOW, Salix-

BABYLON, WEEPING WILLOW, S. babylonica-Slender drooping, dark colored branches golden, similar to Babylon with gold. yel. branches.

$$
\begin{aligned}
& 5 \text { to } 6 \mathrm{ft} ., \quad \$ 1.50 \text { each; } \\
& 4 \text { to } 5 \mathrm{ft} \text {., } \$ 1.00 \text { each; }
\end{aligned}
$$

WISCONSIN, S. blanda-Spreading drooping branches, long shape leaves.

Same price as above (Babylon)

GOLDEN, S. vitellina-Yellow graceful branches, whitish green leaves. Same price as above (Babylon) 


\section{FRUIT TREES}

In listing of Fruit Stocks we include Apple, Pear, Cherry, Plum, Prune, Peach, Apricot, Nectarine and Quince; and a variety of Small Fruits of the different Berry Plants, Grape Vines, etc. (See pp. 42 and 43 for Nut Trees.)

Suggestions relative to your particular needs we shall gladly furnish upon application.

In these as well as in all other plants, trees and shrubs listed we can assure you first quality stock only. The prices designated are fixed upon this basis.

We realize that you will expect satisfaction from well selected stock and we want you to come back again. This is our reason for putting Quality first.

\section{APPLES}

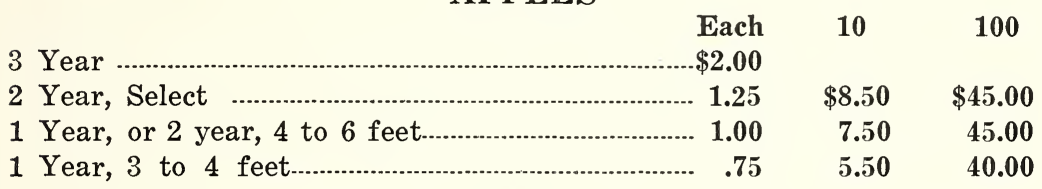

Early Harvest-Yellow Late July \& Aug. Golden Sweet-Large, yellow, cooking...................................................................ug. Red June-Medium, oblong, red. July

Red Astrachan-Large, deep crimson, rich, acid flavor. Early Aug. Yellow Transparent-Medium, juicy, hardy, sub-acid, trees bear young, Best Early apple July

\section{MID-SUMMER}

Duchess of Oldenberg-Large, striped red and yellow, bears young, productive Aug.

Gravenstein-Large, dashed, deep red and orange, aromatic, flavor best Aug.

Dutch Mignonne-Striped and splashed, regular annual bearer.......Aug. \& Sept.

\section{FALL}

Alexander-Large, red-striped, cooking Oct.

Fall Pippin-Yellowish green, cooking, good. Sept. \& Oct. Pumpkin-Sweet, large, mellow, baking. Sept.

Waxen-Medium, pale yellow, crisp, acid, drying and sauce Oct.

\section{EARLY WINTER}

Fameuse (or Snow)-Red on sunnyside, flesh, white Wealthy-Medium, red, hardy, early bearer. Nov. \& Dec. McIntosh Red-Hardy, dessert, best early winter. Nov, to Feb. King-Large, striped red, productive, cooking Nov. to Feb. Jonathan-Vigorous, hardy, red, good bearer, fine Nov, to Feb. Grimes Golden-Rich, golden yellow, good .. Oct. to Jan. ..Nov. \& Dec. 


\section{WINTER}

Arkansas Black-Medium, dark maroon, firm, long keeper.............Dec. to Mar. Baldwin-Large, red Nov. to Feb. Banana Winter-Large, shaded, yellow, oblong..................................Nov. to Jan. Ortley (White Bellflower) - Fine flavored.........................................Dec. to Mar. Northern Spy-Large, striped, red, crisp, tender, juicy.....................Dec. to Mar. Red Cheek Pippin-Yellowish green, red cheek, late keeper.............Dec. to Mar. Yellow Bellflower-Large, oblong, juicy... Oct. to Feb. Wagner-Early bearer, fine grained, good keeper............................... Oct. to Feb. Yellow Newton Pippin-Long keeper, firm, juicy................................Jan. to May Rhode Island Greening-Large, greenish yellow, tender, crisp, cooking

Dec. to Feb.

Rome Beauty_Large, yellow, shaded, bright red, shipper...............Dec. to Mar.

Winesap-Medium, yellow ground, streaked red, shipper.................Dec. to Apr.

Stayman Winesap-Yellow striped red, firm, rich. Dec. to Mar. Lady Apple-Small, flat, red cheek, Christmas fruit............................ Dec. to Jan. Tolman's Sweet-Medium, tinged red, firm, sweet Nov. to Jan. Delicious-Red, dessert Nov. to Feb.

Spitzenberg-Large, striped red, juicy, rich flavor Dec. to Apr.

\section{CRAB APPLES}

Transcendent-Large, yellow, striped red, best. Sept. Yellow Siberian-Small, golden, yellow, good. Sept. Hyslop-Deep crimson Oct.

Red Siberian-Yellow striped, red Oct. Whitney No. 20-Large, striped red, juicy, good. Sept.

\section{APRICOTS}

\begin{tabular}{|c|c|c|c|}
\hline & Each & 10 & 100 \\
\hline 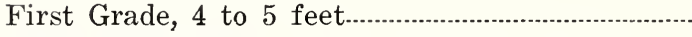 & $\$ 1.00$ & $\$ 7.50$ & $\$ 55.00$ \\
\hline 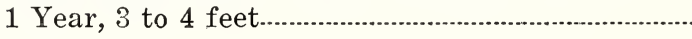 & .85 & 6.50 & 40.00 \\
\hline
\end{tabular}

Moorpark-Large, yellowish green and red, flesh orange, canning and drying July

Royal-Medium, sweet, rich in sugar, dryer and canner...............................July

Tilton-Large, highly flavored, ripens evenly all over, very productive, later than Royal, best for northwest..........................................July

Blenheim-Deep orange, rich July 


\section{CHERRIES}

\begin{tabular}{|c|c|c|c|}
\hline & $\begin{array}{r}\text { Each } \\
\$ 2.50\end{array}$ & 10 & 100 \\
\hline & 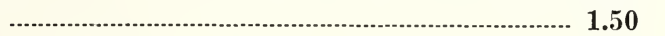 & $\$ 12.50$ & $\$ 90.00$ \\
\hline & 1.25 & 10.00 & 75.00 \\
\hline & 1.00 & 8.50 & 70.00 \\
\hline
\end{tabular}

Those marked (P.) used as pollonizers.

Bing-Large, dark brown and black, fine shipper.

July

English Morello-Early and Prolific bearer, tree low spreadingtype, acid, pie

Kentish (Early Richmond) - Pie, dark red, juicy, productive........... June \& July

Lambert-Large, quality best, deep rich red color, firm, shipper........July-Aug.

Late Duke-Large, light red, late, excellent, sub-acid.............................July-Aug.

May Duke-Large, red, tender, juicy, acid, light bearer.....................................June

Major Francis-Ripens early, spicy, dessert. June

Montmorency-Canning, preserving, pie, acid, large, best in Morello class

(P) Oregon-Large, black, shipper

(P) Republican (Lewelling)-Medium, large, firm, black, sweet, shipper

Royal Ann-(Napoleon Bigarreau)-Large, firm, juicy, sweet, dessert, canning

(P) Tartarian Black-Large, purple, juicy, good, early.

Black-Large, purple, juicy, good, early_..................................June

\section{PEARS}

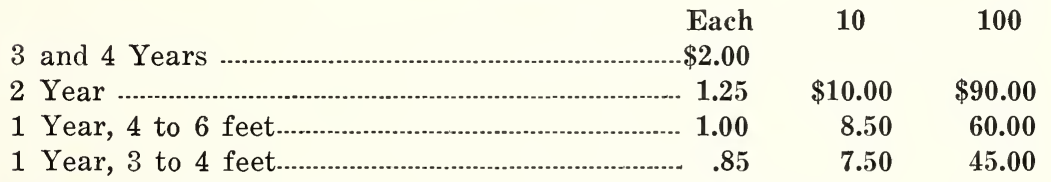

Bartlett-Large, lemon yellow, soft red blush, butter, home canning, good bearer, best summer pear.

Aug. \& Sept. Bosc-Large, russety, highly flavored, good shipper.......................... Sept. to Nov.

B. Clairgeau-Large, yellow, shaded crimson, russet dots, ship-

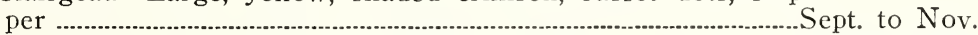

Buerre Easter-Oval, yellow, red cheek, winter.

Dec. to Feb.

Clapp's Favorite-Large, pale yellow, fine grained, earliest good

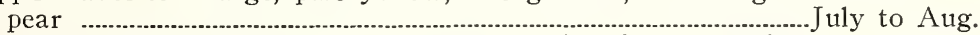

Comice-Shipping variety, good appearance, fine flavor, medium

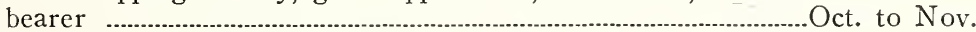

Flemish Beauty-Large, beautiful, rich, sweet, pale yellow, slight russett, tree hardy, best for cold sections......................................Sept. \& Oct.

Fall Butter-Yellow, sweet, baking.

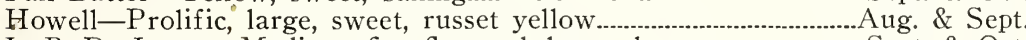

Sept. \& Oct.

L. B. De Jersey-Medium, fine flavored, heavy bearer.........................Sept. \& Oct.

P. Barry-Good keeper, medium, juicy, russet......................................... to Feb.

Seckel-Rich, spicy, russet, preserving, dessert......................................... Sept. \& Oct.

Winter Nellis-Medium, fine grained, aromatic........................................ Dec. to Feb.

Winter Bartlett-Resembles Bartlett in form and color, season same as Winter Nellis, good Winter.

Dec. to Feb. 


\section{PEACHES}

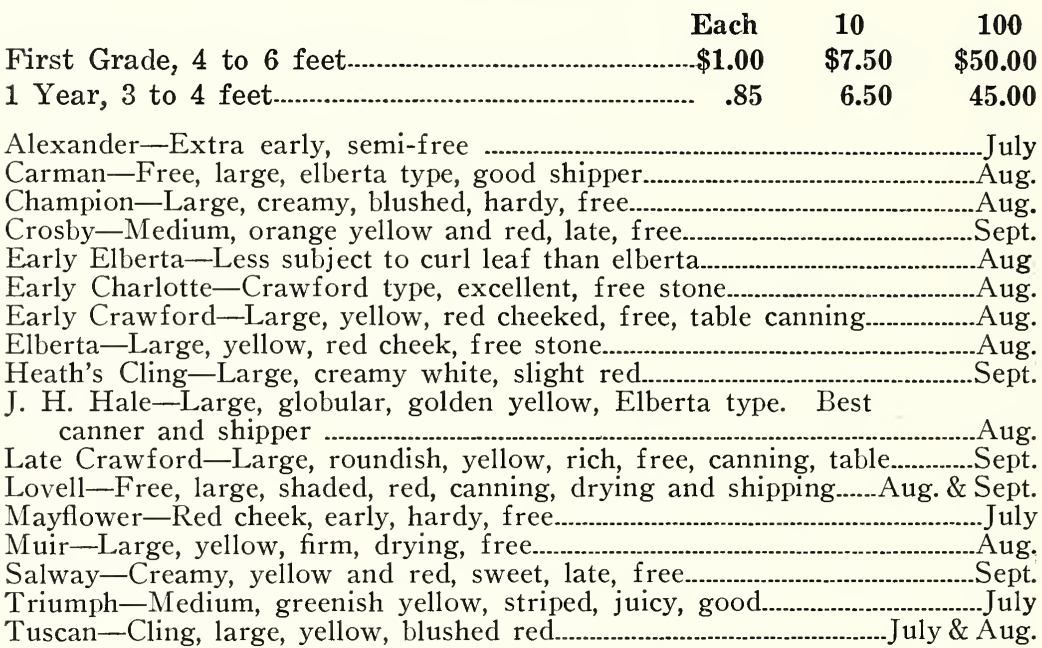

\section{PLUMS (on Peach Root)}

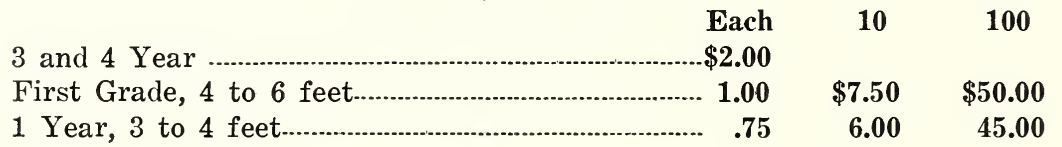

\section{PLUMS (on Myrobolan Root)}

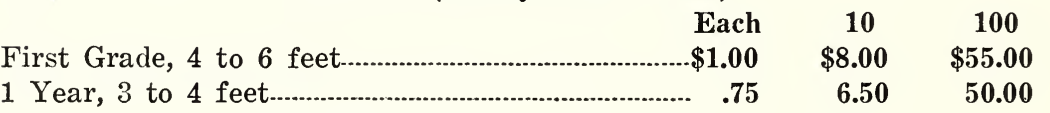

Abundance-Large, beautiful, bright cherry, juicy, sweet, productive, free

Apex Plumcot-A cross between Plum and Apricot, globular, light

crimson, free, firm, apricot-like

Bradshaw-Reddish purple, juicy and pleasant

Columbia-Large, globular, brownish purple, rich, free.

Damson-Small, oval, bluish purple, tart, fruitful, hardy.

June

Damson Shropshire-Medium size, dark purple, flesh greenish.

Wickson (Jap) - Large, heart shaped, deep red.

Reine Claude-Greenish color, marked red, firm flesh

Coe's Golden Drop-Smaller than Silver Prune, sweet.

July

July

Aug.

Aug.

Sept.

Satsuma (Jap) - Quite popular, large, dark red, firm and juicy....................July

Maynard (Jap) - Dull red, large, round and firm, rich and sweet.................July

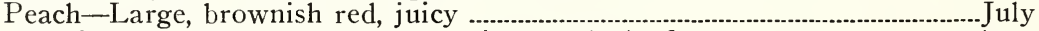

Washington-Large, dull yellow, crimson blush, firm, sweet..............................ug.

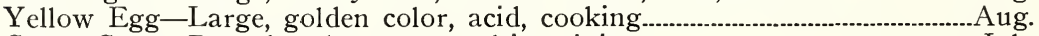

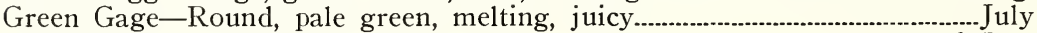

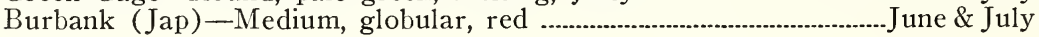




\section{PRUNES}

\begin{tabular}{|c|c|c|c|}
\hline & Each & 10 & 100 \\
\hline 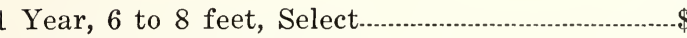 & $\$ .75$ & $\$ 5.00$ & $\$ 35.00$ \\
\hline 4 to 6 & .65 & 5.00 & 30.00 \\
\hline 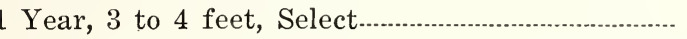 & .50 & 3.00 & 20.00 \\
\hline
\end{tabular}

Date Prune-Large, high sugar content, heavy bearer, best drying and canning variety

Aug. \& Sept.

Giant-Large, good quality.

Hungarian-Large, dark red, juicy, sweet.

Sugar-Early, tender, rich, sweet, dark purple.

Aug.

Pacific-Large, sweet Aug.

Petite (French)-Medium, violet, purple, sweet, sugary.................Aug. to Sept.

Tragedy-Dark purple, sweet July

Silver-Similar to Coe's Golden Drop, large.

Sept.

Italian (Fellenberg)-Large, dark purple, drying

Aug. to Sept.

New Standard (Burbank Production)—Skin purple, juicy

Aug.

\section{NECTARINES}

Each $\quad 10 \quad 100$

First Grade, 4 to 6 feet $\$ 1.00$

Boston-Large, deep yellow, rich, luscious Aug.

Early Violet-Medium, pale, shaded violet. July

New White-Large, white, juicy, rich July \& Aug.

\section{QUINCES}

First Grade

Each

Per 10

$\$ 1.00$

$\$ 9.00$

Champion-Large, flavor delicate, greenish yellow

Oct.

Meech's Prolific-Large, bright yellow, mid-summer. Oct.

Orange-Roundish, golden yellow Oct.

Pineapple-Best for home use, large Oct.

Consult our Spray Calendar on Page 47 


\section{NUT TREES}

In this Pacific Coast Region there are great possibilities for the commercial growing of Nut Crops.

Those listed here are well suited for the Northwest and to the best of our knowledge never result in failure. For your particular location we shall gladly supply accredited information as to the best sort to plant.

NUT BEARING TREES PRODUCE A STEADY INCOME.

\section{ALMOND}

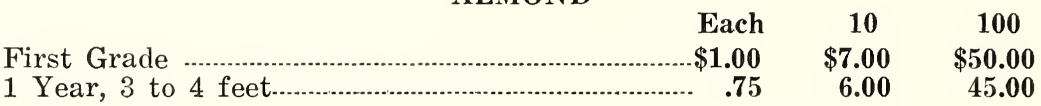

I. X. L.-Vigorous grower, sure cropper, nuts large size, shell thin. NONPARIEL-Tree beautiful, nut sweet, shell very thin.

NE PLUS ULTRA-Large; soft shell; hulls free, regular bearer.

\section{HICKORY}

Each

4 to 6 feet $\$ 1.50$

SHELLBARK-Tree hardy, slow grower.

\section{CHESTNUT}

Same Price as Butternut

AMERICAN SWEET-Handsome tree, medium size, sweet nuts.

SPANISH-Handsome lawn tree, larger fruit than American variety. MAMMOTH JAPANESE-Largest fruit, not so sweet as American.

\section{BUTTERNUT (White Walnut)}

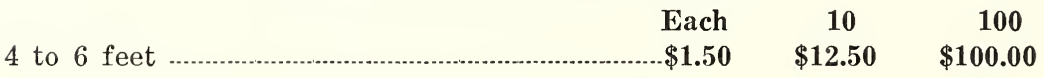

Beautiful tree, rough coated nut, flavor rich.

In the selection of Walnuts, the same as in other trees, we urge the greatest care in choosing your stock. Scion selection is very important. All trees herein listed are propagated with scion-wood from known bearing trees only.

\section{WALNUTS-GRAFTED ON CALIFORNIA BLACK}

\begin{tabular}{|c|c|c|c|c|c|c|}
\hline & & & & Each & Per 10 & Per 100 \\
\hline 8 to $10 \mathrm{ft}$. & Extra & Large & Grade & $\$ 3.00$ & $\$ 27.00$ & $\$ 250.00$ \\
\hline 7 to $8 \mathrm{ft}$. & Large & Grade & 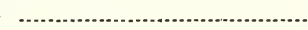 & 2.50 & 22.50 & 185.00 \\
\hline $7 \mathrm{ft}$. & "6 & “ & 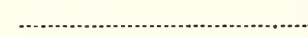 & 2.25 & 20.00 & 160.00 \\
\hline $6 \mathrm{ft}$. & “ & “ & 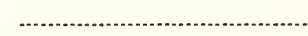 & 2.00 & 17.50 & 145.00 \\
\hline 4 to $5 \mathrm{ft}$. & “ & “ & 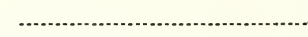 & 1.75 & 15.00 & 130.00 \\
\hline
\end{tabular}

FRANQUETTE GRAFTED WALNUT-Elongated oval nut, kernel full, sweet, rich flavor.

MAYETTE GRAFTED WALNUT-Nuts large and round, generally full kernel. 


\section{American Black, California Black}

Each

4 to 6 feet

$\$ 1.50$

$\$ 12.50$

$\$ 100.00$

JAPANESE WALNUT-Similar to native Black Walnut in habit and growth. Nuts fine quality.

Same price as black walnuts

\section{FILBERTS}

Each $\quad 10 \quad 100$

First Grade $\$ .75$

1 Year, 3 to 4 feet.

.65

5.00

45.00

BARCELONA-Large round nut-good cropper.

DuCHILLY-Long shaped, large nut. Often used as pollenizer.

DAVIANA-(Pollenizer)—Good cropper, rich flavor.

AVALINE, WHITE (Pollenizer)—Good cropper, rich flavor.

Nut Trees-especially Walnuts, are several years of age before coming into bearing.

Fillers are often advisably worked in such plantings and we shall gladly advise you upon suitable fruits for that purpose. 


\section{SMALL FRUITS}

\section{AMERICAN GRAPES}

\begin{tabular}{|c|c|c|c|}
\hline & Each & 10 & 100 \\
\hline 3 Year & $\$ .35$ & $\$ 2.50$ & \\
\hline 2 Year, No. 1 . & .25 & 2.00 & $\$ 17.50$ \\
\hline
\end{tabular}

ISABELLA-Black, large bunch, good shipper, vigorous.

CAMPBELL'S EARLY-Large, black to purple, rich, sweet.

MOORE'S DIAMOND-Bunches large, greenish white.

MOORE'S EARLY-Bunch medium, resembling Concord, earlier.

WORDEN-Bunch large, berry large black, improved Concord.

GREEN MOUNTAIN-Greenish white, sweet, fine.

BRIGHTON-Large, sweet, red grape.

CONCORD—Large, black grape.

DELAWARE-Ripens early, berries small, light red.

EATON-Vigorous grower, large, round, black.

NIAGARA-Large, pale yellow, best white grape.

SWEETWATER-Small white, sweet grape.

\section{FOREIGN GRAPES}

See above prices.

FLAMING TOKAY-Light red, fine table sort.

MALAGA-Large, yellowish green.

BLACK HAMBURG-Large, coal black, sweet.

SULTANA-Small, amber color, seedless.

MUSCAT-Raisin variety .

\section{ASPARAGUS ROOTS}
1 Year
Per 100
Per 1000
$\$ 3.00$
$\$ 25.00$

CONNOVER'S COLOSSAL-Best for general planting.

COLUMBIAN MAMMOTH-Large, white.

PALMETTO-Enormous and delicious spikes.

WASHINGTON-Nerw Rust-resistant.

\section{RHUBARB}
2 Year Transplants
Each

MYATT'S LINNAEUS-Large, early, hard to equal.

VICTORIA MAMMOTH-Large, long stalks, splendid market sort. RIVERSIDE GIANT-Extra large, splendid canning fruit.

EARLY STRAWBERRY-Stock short, juicy, highly flavored, early. 


\section{RASPBERRIES}

\begin{tabular}{|c|c|c|c|}
\hline & Each & 100 & 1000 \\
\hline La France ....... & $\$ .25$ & $\$ 12.50$ & $\$ 75.00$ \\
\hline St. Regis & .25 & 12.50 & 75.00 \\
\hline 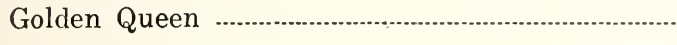 & .25 & 12.50 & 75.00 \\
\hline 11 other varieties & $\begin{array}{l}\text { Each } \\
\$ .15\end{array}$ & $\begin{array}{c}10 \\
\$ 1.50\end{array}$ & $\begin{array}{c}100 \\
\$ 7.50\end{array}$ \\
\hline
\end{tabular}

ST. REGIS-Everbearing, large, beautiful, firm.

LA FRANCE-Everbearing, large, juicy fruit.

CUTHBERT-Rich red, firm, market berries.

MARLBORO-Light crimson, large, ripens early.

GOLDEN QUEEN-Yellow fruit, large, hardy.

KANSAS BLACK-Large, moderately juicy, ripens early.

CUMBERLAND-Large, firm, quality same as Gregg.

GREGG-Best known market sort, productive.

PLUM FARMER-Profitable early market, large, firm.

COLUMBIAN-Large, purplish color.

\section{BLACKBERRIES}

$\begin{array}{lllrr} & & \text { Each } & 10 & 100 \\ \text { Corey's Thornless } 2 \text { yr. transplants } & \$ & \$ 35 & \$ 3.00 & \$ 20.00 \\ \text { Regular varieties } & \cdots & .25 & 2.00 & 15.00\end{array}$

BLOWERS-Productive, sweet. July.

NEW MAMMOTH (Vine)-Trailing habit, large.

KITTATINNY-Large, roundish, glossy black. July.

ELDORADO-Large, melting, sweet, rich, hardy.

COREY'S THORNLESS (Vine)—Thornless blackberries, fruit, small core, almost seedless.

LAWTON-Large, very productive.

EVERGREEN (Vine)-Long, black, sweet, rich and delicious. July to November.

HIMALAYA GIANT (Vine)-Strong grower, enormous yielder.

\section{CURRANTS}

2 Year Transplants

Each

$\$ .25$

10

$\$ 2.00$ 100 $\$ 15.00$

PERFECTION-Large, prolific, red, rich flavor.

WHITE GRAPE CURRANT-Valuable for the table.

CHERRY-Large, deep red, for preserving and market.

FAY'S PROLIFIC-Bright red, fruit hangs on.

VICTORIA-Bright red bunches, long, late.

\section{GOOSEBERRIES}

OREGON CHAMPION-Best canning and preserving gooseberry grown on Pacific Coast. 


\section{STRAWBERRY PLANTS}

Per 100 Per 1000

Everbearing (Progressive) and Superb $\$ 2.50$

$\$ 20.00$

All other varieties 2.00

15.00

IMPROVED OREGON-Fine cropper, fruit large, firm, rich, delicious, table canning.

Other varieties of Strawberries suited for North Pacific Coast are Gold Dollar, Clark Seedling, Magoon, Marshall, Wilson. 


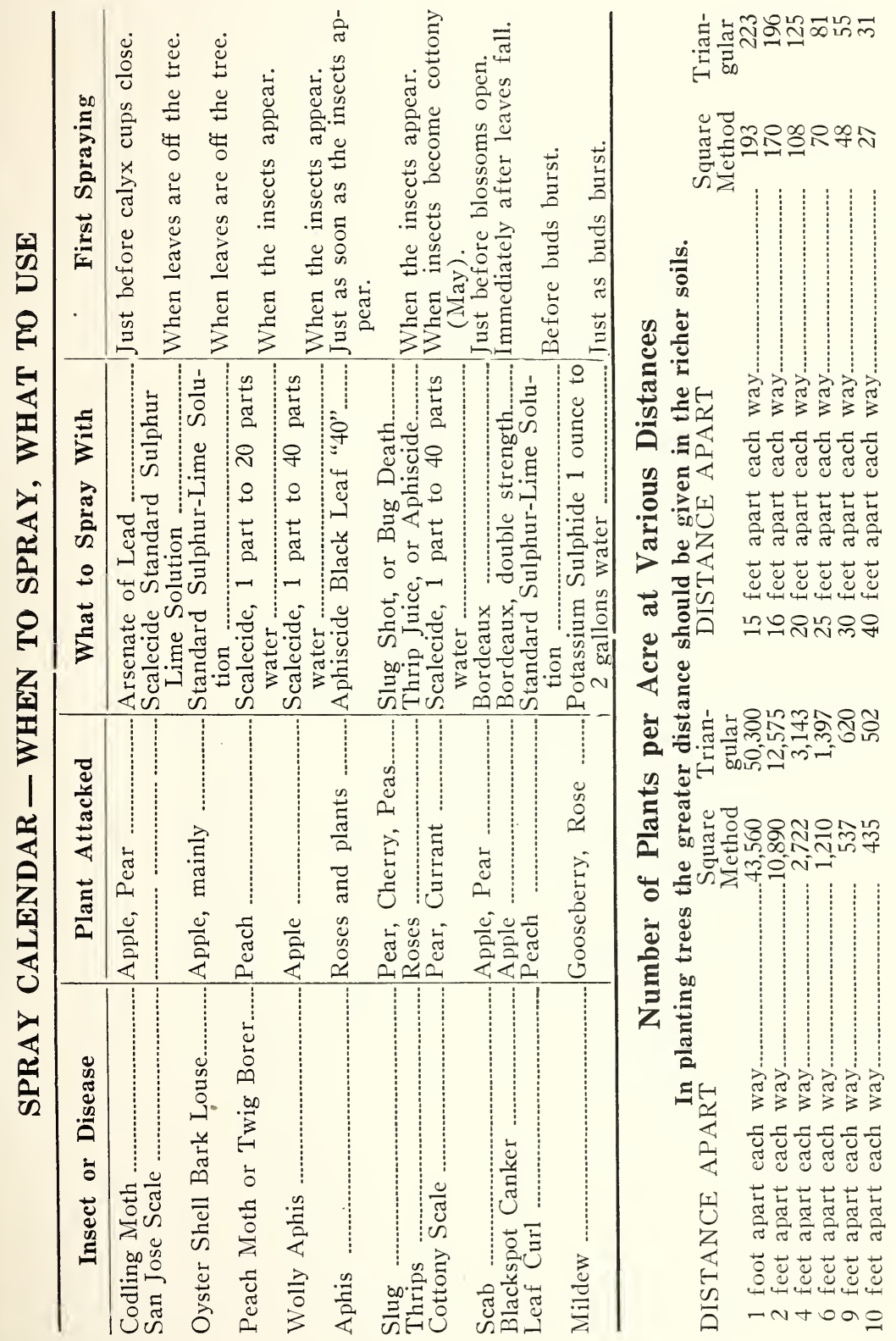





\section{INDEX}

Broadleaf Evergreens.

Conifers

7-12

Deciduous Flowering Shrubs

20-27

Deciduous Trees (Shade Trees)

30-36

Fruit Trees

$37-41$

Hedge Plants

27

Nut Trees

$42-43$

Roses

1- 6

Spray Calendar

Small Fruits (Berry Vines)

44-46

Vines and Climbers. 


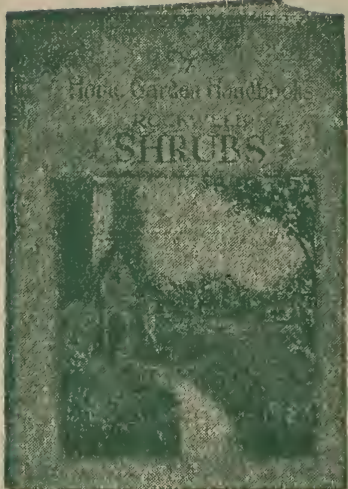

EVERGREENS FOR THE SMALL PLACE, by F. F. Rockwell. All the information you need to make the best use of evergreens is in this handy book, written by one who is himself a home owner and a garden maker. It tells the uses, characteristics, and types of small or dwarf evergreens, and details of their planting, transplanting, and general care. 67 illustrations, 84 pages.

$\$ 1.00$

THE CARE OF ORNAMENTAL TREES, by C. H. Greeves-Carpenter. This book outlines all the operations in tree care; the precautions necessary in transplanting; the best time and methods for pruning; how the soil, age, and kind of tree affects the choice and application of plant food; types of cavity fillings; with the best methods for cabling and bracing. 7 illustrations, 70 pages.

$\$ 1.25$

AROUND THE YEAR IN THE GARDEN, by F. F. Rockwell. This splendid book, written by one of America's best known practical gardeners, is unique in its usefulness. It starts with preparations for the season's work in January and outlines a balanced program for the garden through every week in the year. Bound to bring you success. 88 illustrations, 350 pages.
SHRUBS, by F. F. Rockwell. Here is brief but complete and usable information on the best ways to improve the beauty and value of your home with shrubs. Tells what to select for different combinations and effects, and how to plant, water, mulch, prune, and care for shrubs. 49 illustrations, 76 pages.

$\$ 1.00$

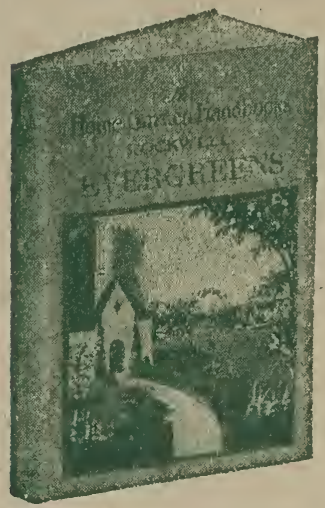

THE DESIGN OF SMALL PROP. ERTIES, by M. E. Bottomley. Small homes benefit fully as much from proper planting as large estates. Here is a book which shows youwith more than 50 sample layouts -just how to choose, set out, and care for the plants that will beautify your home property. Add a room to your house by making your yard more livable. 64 illustrations, 233 pages.

$\$ 3.00$

THE GARDENER, by L. H. Bailey. This book gives you the very essence of Dr. Bailey's unequalled knowledge of gardening. It tells how to grow flowers, vegetables, and fruits from the time of planting through to maturity. Special articles on different types of gardening. Arranged alphabetically. 116 illustrations, 260 pages. $\$ 2.50$

\section{Russellville Nurseries}

East 96th and Burnside Sts.

Portland, Oregon 